\title{
Flora da Reserva Ducke, Amazonas, Brasil: Euphorbiaceae - Parte I
}

Ricardo de S. Secco ${ }^{1}$

Euphorbiaceae Gen. Pl. 384. 1789.

Mueller, J. 1874. Euphorbiaceae. In Martius, C. F. P. ed., Fl. bras. 11(2): 1-752.

Secco, R. S. 1990. Revisão dos gêneros Anomalocalyx, Dodecastigma, Pausandra, Pogonophora e Sagotia (Euphorbiaceae) para América do Sul. Mus. Para. Emilio Goeldi, col. Adolfo Ducke, 133 p.

Secco, R. S. 1997. Revisão taxonômica das espécies neotropicais da tribo Alchorneae (Euphorbiaceae). Tese de Doutorado, USP, 485 p.

Secco, R. S. 2004. Alchorneae (Euphorbiaceae): Alchornea, Aparisthmium e Conceveiba. Fl. Neotropic. Monograph 93: 1-194.

Webster, G. L. \& Huft, M. J. 1988. Revised Synopsis of Panamanian Euphorbiaceae. Ann. Missouri Bot. Gard. 75: 1087-1144.

Webster, G. L. 1994. Synopsis of the genera and suprageneric taxa of Euphorbiaceae. Ann. Missouri Bot. Gard. 81: 33-144.

Árvores, arbustos, ervas ou lianas, monóicos ou dióicos; caules com resina ou látex. Folhas peninérveas ou palmatinérveas, alternas ou opostas, raramente verticiladas, com indumento de tricomas simples, estrelados ou escamosos (lepidotos); limbo inteiro ou lobado, simples ou composto; estipulas persistentes a caducas. Inflorescências terminais, axilares ou caulifloras, em espigas, racemos, panículas ou agregadas em pseudantos; flores solitárias, aos pares ou em glomérulos. Flores unissexuais, as estaminadas geralmente em maior quantidade, as pistiladas solitárias ou agrupadas em menor quantidade; cálice gamossépalo ou dialissépalo; pétalas presentes ou ausentes; disco intraestaminal ou extraestaminal presente ou ausente; estames hipóginos, com filetes livres ou concrescidos, anteras 2-loculares, com deiscência longitudinal, introrsas ou extrorsas; estaminódios algumas vezes presentes; ovário 2-5-locular (comumente 3-locular), óvulos 1 a 2 por lóculo, estiletes livres ou concrescidos, inteiros ou lo- bados. Fruto geralmente esquizocarpo capsular, com mericarpos deiscentes, às vezes baga ou drupa; sementes 1 ou 2 por lóculo, algumas vezes com sarcotesta, superfície lisa a muricada, pintalgadas, marmóreas ou sem ornamentação; endosperma presente ou ausente.

A família apresenta 317 gêneros e mais de 7.000 espécies, com distribuição paleotropical e neotropical. É um grupo com morfologia bastante diversificada e complexa, representado por 27 gêneros e cerca de 50 espécies na Reserva Ducke. No presente tratamento são apresentados 15 gêneros e 20 espécies, devendo os demais táxons ser publicados na Parte II.

A família reúne algumas espécies de interesse econômico, destacando-se Hevea brasiliensis Müll. Arg. (seringueira), Manihot esculenta Crantz (mandioca ou cassava), Ricinus comunis L. (óleo de ricino, castor oil), Croton cajucara L. (sacaca, rica em linalol) e Phyllanthus niruri L. (quebrapedra).

\section{Chave para os gêneros de Euphorbiaceae (Parte I) na Reserva Ducke}

1. Folhas com margem inteira (ou espaçadamente denteada em Croton draconoides e Richeria).

2. Folhas com base trinervada.

3. Inflorescências estaminadas em racemos espiciformes; frutos cápsulas ... 10. Alchorneopsis

3. Inflorescências estaminadas em panículas; frutos drupas 15. Glycydendron 
2. Folhas com base não trinervada.

4. Flores estaminadas com pistilódios.

5. Flores estaminadas com cálice gamossépalo, lobos valvares.

6. Folhas com pecíolo enegrecido no material seco; flores com pétalas ..... 13. Amanoa

6. Folhas com pecíolo sem essa característica; flores apétalas 14. Micrandra

5. Flores estaminadas com cálice dialissépalo, sépalas imbricadas 5. Pogonophora

4. Flores estaminadas sem pistilódios.

7. Estames 3-12.

8. Folhas glabras; flores estaminadas monoclamídeas; estames 3-6; frutos piriformes, mericarpos não dilatados 4. Richeria

8. Folhas com indumento de tricomas estrelados ou escamosos (lepidotos); flores estaminadas diclamídeas; estames 11-12; frutos padrão tricoca, mericarpos dilatados

12. Croton

7. Estames numerosos (sempre acima de 12).

9. Estames 5-10 mm compr., filetes finos; flores pistiladas com pétalas minúsculas, decíduas; frutos médios (1,2-1,5 cm compr.); sementes carunculadas, lisas ...... 8. Sandwithia

9. Estames 1-2 mm compr., filetes grossos; flores pistiladas com pétalas maiores, não decíduas; frutos grandes (2,5-4 cm compr.); sementes ecarunculadas, rugosas

6. Anomalocalyx

1. Folhas com margem tipicamente crenada.

10. Flores pistiladas com pétalas pubescentes na face interna; folhas com pecíolos curtos, enegrecidos no material seco

7. Pausandra

10. Flores pistiladas apétalas; folhas com o pecíolo sem essa característica.

11. Flores pistiladas com cálices gamossépalos.

12. Inflorescências caulifloras; estames 8, com filetes, formando uma estrutura plana, discóide, frutos não ferrugíneos 1. Alchornea

12. Inflorescências não caulifloras; estames 10-17, sésseis, constituidos por uma grande antera; frutos ferrugíneos

3. Nealchornea

11. Flores pistiladas com cálices dialissépalos.

13. Flores estaminadas com estaminódios; flores pistiladas com cálices glandulosos na base

9. Conceveiba

13. Flores estaminadas sem estaminódios; flores pistiladas com cálices não glandulosos 14. Folhas com estipelas lanceoladas no ápice dos pecíolos, bases arredondadas a levemente cordadas; flores pistiladas com 4 sépalas, ovário não lobado, estigmas não sésseis

2. Aparisthmium

14. Folhas sem estipelas lanceoladas, bases longamente cuneadas; flores pistiladas com 3 sépalas, ovário 3-lobado, estigmas sésseis 11. Adenophaedra

\section{Alchornea}

Alchornea Sw., Prodr. 6: 98. 1788.

Arbustos, arvoretas a árvores, raro lianas, dióicos, raro monóicos. Folhas alternas, estípulas ausentes ou obsoletas a caducas, nervuras peninérveas ou palmatinérveas; margem crenada a serrilhado-glandulosa, raro inteira ou ondulada. Inflorescências estaminadas em panículas ou racemos espiciformes; inflorescências pistiladas em racemos, raro panículas; inflorescências bissexuadas em panículas espiciformes. Flores monoclamídeas com 1 bráctea externa e 2 bractéolas internas; as estaminadas em glomérulos, as pistiladas isoladas, aos pares ou em tríades; flores estaminadas com cálice gamossépalo, valvar, estames (6)-8, concrescidos pela base, formando uma estrutura plana, discóide, anteras ovais, deiscência lateral; flores pistiladas com cálice 
gamossépalo, raro dialissépalo (em $A$. castaneifolia (Wild.) Adr. Juss.), ovário oval, piriforme, elíptico a globoso, 2(3)-locular, raro 4-5 locular (A. fluviatilis R. Secco), pubescente a tomentoso, raro glabro, estiletes 2-3, raro 4-5, livres a levemente concrescidos na base. Fruto cápsula loculicida, 2(3) mericarpos; sementes (1) 2-3 (-5), tegumento interno muricado a rugoso, ecarunculadas.

Gênero representado por 41 espécies tropicais (na Ásia, África e América), sendo que no neotrópico ocorrem 22. O centro de diversidade é na Colômbia, onde estão representadas 16 espécies. Na Reserva Ducke ocorre apenas Alchornea discolor.

1.1 Alchornea discolor Poepp., Nov. Gen. Sp. Pl. 3: 19. 1841. Fig. 1

Alchornea schomburgkii Klotzsch, Lond. J. Bot. 2: 46.1843.

Árvores ou arbustos 2-20 malt., 5-27 cm DAP, dióicos. Ramos rugosos, lenticelados, glabros. Folhas peninérveas, pecíolo 0,5$3,5 \mathrm{~cm}$ compr., canaliculado, tricomas estrelados; limbo 3-17×2,5-8 cm, elíptico, elíptico-oblongo a elíptico-lanceolado, raros oval, coriáceo (cartáceo nos indivíduos jovens e na fase vegetativa da planta), discolor, ápice acuminado a agudo, às vezes arredondado, base obtusa, margem crenado-glandulosa; face adaxial verde-escura, nervuras proeminentes a impressas, indumento de tricomas estrelados concentrados na nervura principal; face abaxial arroxeada na fase jovem, verde-clara a acinzentada na maturação, com nervuras proeminentes, esparso indumento de tricomas estrelados mais evidentes nas nervuras, domácias de tricomas na junção da nervura principal com as secundárias. Inflorescências estaminadas em panículas, caulifloras, 10-30 cm compr., flores dispostas em glomérulos, envolvidas por uma bráctea sagitada, pilosa, raque com denso indumento de tricomas estrelados, verde-clara a acinzentada. Flores com pedicelo 0,5-1 mm larg., glabros; cálices com lobos 2-3(4), ovais a sagitados, 1-1,5 mm compr., glabros; estames
8, 1-1,5 mm compr., anteras cremes, filetes levemente rugosos. Inflorescências pistiladas em racemo, às vezes em panículas espiciformes, caulifloras, $10-25 \mathrm{~cm}$ compr., flores isoladas, aos pares ou em tríades, raque com indumento tomentoso de tricomas estrelados, acinzentada; flores subsésseis ou sésseis, raro pediceladas (pedicelos $0,5-0,7 \mathrm{~mm}$ compr.); cálice cupuliforme, lobos 2-4, sagitados, densamente pilosos externamente, 1-2 mm compr., ovário subgloboso a globoso, denso-tomentoso, 1-3 mm compr., 1,5-2,5 mm larg., 2(3)-locular, estiletes 2(3) filiformes, livres, 1-3 cm compr., pilosos na face externa. Frutos elípticos a piriformes, mericarpos 2(3), 0,7-1,5 cm diâm., vináceo, pubescentes; sementes (1)2(3), ovais, elípticas a subglobosas, 0,5-0,6 cm compr., testa carnosa, vermelha, levemente muricadas.

Colômbia, Venezuela, Guianas, Peru, Bolívia e Brasil (Amapá, Pará, Amazonas, Acre, Rondônia, Roraima, Mato Grosso, Goiás, Bahia, e Pernambuco).

Nome vulgar: Supiarana (Amazonas e Rondônia).

5.X.1994 (bt) Sothers, C. A. et al. 202 (INPA K MG MONY RB SPUUB).

Material adicional: Manaus, Ponta Negra, 18.V.1992 (fl), Secco \& Coelho 800 (MG INPA); rio Urubu, 20. XII.1966 (fl fr), Prance et al. 3756 (INPA MG NY); estrada do Aleixo, 5.X.1943 (fl), Ducke 446 (IAN K NY).

Alchornea discolor é a espécie mais conhecida e amplamente distribuída do gênero na Amazônia. É facilmente reconhecida por apresentar as inflorescências caulifloras e frutos elípticos com 2, raro 3, mericarpos. Nas plantas jovens, observa-se as folhas com as faces abaxiais tipicamente arroxeadas.

\section{Aparisthmium}

Aparisthmium Endl., Gen. Pl. 1112. 1840. (nom. cons. prop. in Webster, Ann. Missouri Bot. Gard. 81: 82. 1994).

Gênero monotípico, com ampla distribuição na América do Sul. No Brasil, ocorre em todas as regiões, especialmente em ecossistemas degradados. 


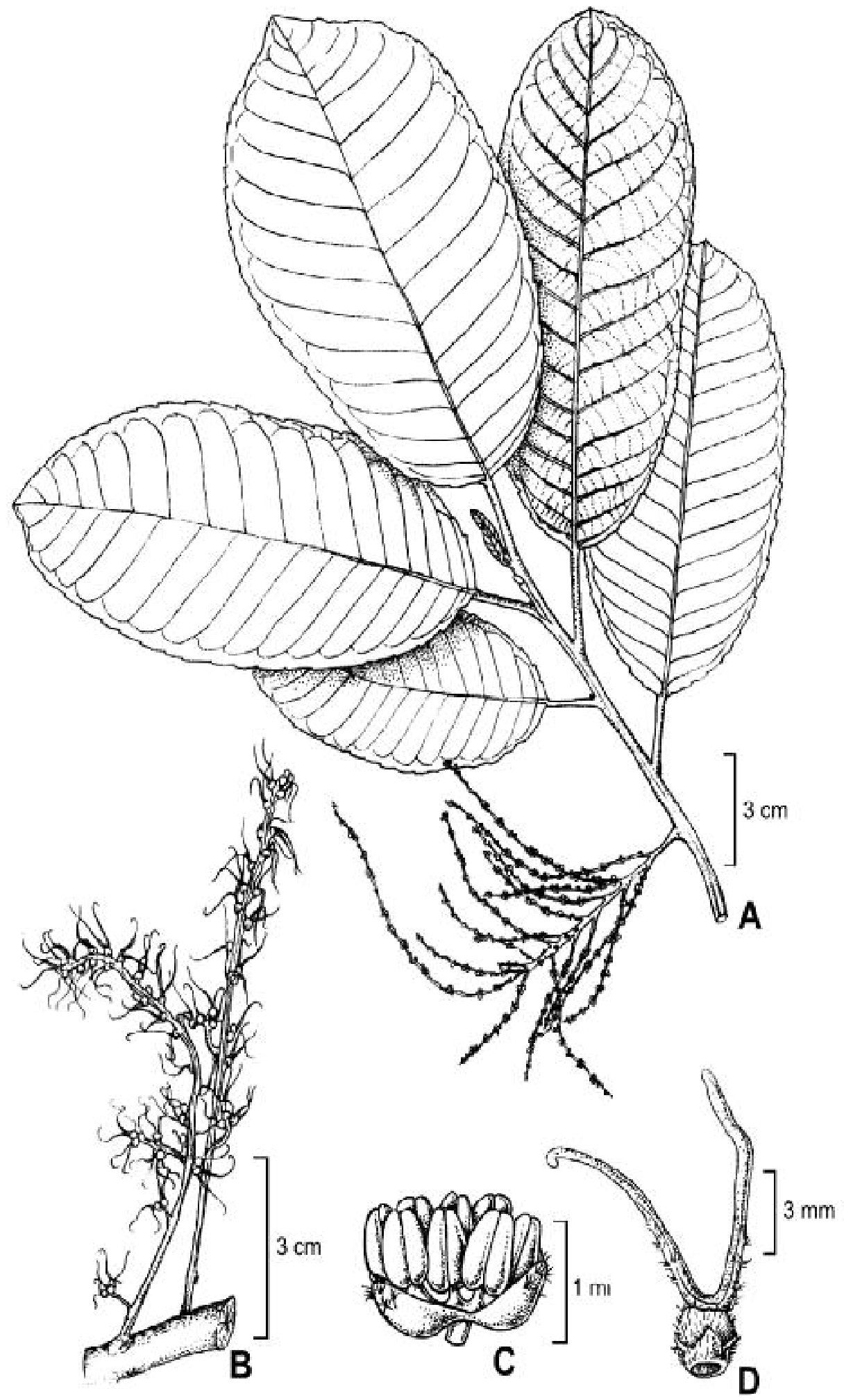

Figura 1 - Alchornea discolor. A. Ramo com inflorescência estaminada. B. Inflorescência pistilada. C. Flor estaminada. D. Flor pistilada. 
2.1 Aparisthmium cordatum (Juss.) Baill., Adansonia 5: 307. 1865. Fig. 2

Conceveibum cordatum Juss., Euph.

Tent. 43, t. 13, fig. 42 A. 1824.

Alchornea cordata (Juss.) Müll. Arg.,

DC. Prodr. 15(2): 901. 1866.

Arbustos, arvoretas ou árvores, 2-

$25 \mathrm{~m}$ alt., 5-20 cm DAP, dióicas, raríssimo monóicas. Ramos levemente estriados a lisos, lenticelados, pubescentes, glabrescentes. Folhas peninérveas, pecíolo 1,5-12 cm compr., levemente canaliculado ou inteiro, pubescente, glabrescente, estipelas 2, apicais, 3-4 $\mathrm{mm}$, lanceoladas; limbo 10-35×7-26 cm, oval, ovalelíptico, cordado, orbicular a lanceoladoelíptico, cartáceo, ápice acuminado, base arredondada a levemente cordada, glândulas basais 2-4, margem crenado-glandulosa; face adaxial com nervuras levemente proeminentes à impressas, pubescentes, tricomas simples mais concentrados nas nervuras; face abaxial com nervuras proeminentes, pubescentes, tricomas simples em toda a lâmina, domácias de tricomas na junção da nervura principal com as secundárias. Inflorescências estaminadas em racemos espiciformes ou espigas, $\quad 10-38 \mathrm{~cm}$ compr.; flores estaminadas monoclamídeas, subsésseis, dispostas em glomérulos multiflorais, bractéolas 3 por flor, 1 externa, 2 internas, cálice gamossépalo, valvar, lobos 3(4), ovais, pubescentes no ápice, 1-1,5 mm compr.; estames 3-5, 1,5-2 mm compr., concrescidos pelas bases, formando um feixe, filetes eretos a levemente dobrados, anteras ovais, deiscência lateral; inflorescências pistiladas em racemos terminais a axilares, $10-38 \mathrm{~cm}$ compr., flores isoladas, raques pubescentes; flores pistiladas monoclamídeas, pedicelo 1,5-3 mm compr., pubescente a tomentoso, bractéolas 1 externa, 2 internas, 1-2 mm compr., pilosas externamente, cálice dialissépalo, sépa-las 4, sagitadas, imbricadas, 2 externas, 2 internas, tomentosas externamente, 1-2 mm compr., 0,5-1 mm larg., ovário subgloboso, trígono, tomentoso, 1,52 mm diâm., 3-locular, estiletes 3, achatados, foliáceos, bífidos, 2-5 mm compr., face interna papilosa. Fruto cápsula septicida, mericarpos 3 , acentuadamente dilatados, $0,5-1 \mathrm{~cm}$ diâm., pubescente; sementes 3, ovais a elípticas, 5$6 \mathrm{~mm}$ compr., 3,5-4 mm larg., discretamente pintalgadas, ecarunculadas.

Colômbia, Venezuela, Guianas, Equador, Peru, Bolívia e em quase todo o Brasil. Espécie muito encontrada em capoeiras da Amazônia e também em florestas primárias.

Nomes vulgares: mameleiro, morocototó (Amazonas).

14.XI.1994 (fr) Nascimento, J. R. et al. 640 (INPA K MGMO NYR RB SP); $14 . I X .1987$ (fl) Pruski, J. F. et al. 3241 (INPAMG R SPUB).

Material adicional: Manaus, Ponta Negra, 7.X.1975 (fl), Albuquerque 1174 (INPA); Manaus, Cachoeira Grande, 22.XI.1942 (fl), Ducke 1042 (MG); Barcelos, serra do Acará, 27.VII. 1985 (fr), Cordeiro 272 (INPA MG). São Paulo de Olivença, 11.XII. 1936 (fr), Krukoff 8998 (MICH).

Aparisthmium cordatum é uma espécie de fácil reconhecimento por apresentar estipelas lanceoladas no ápice do pecíolo, a inflorescência estaminada em racemo espiciforme ou espiga, com as flores reunidas em glomérulos multiflorais, a inflorescência pistilada em racemo ereto, as flores pistiladas com pedicelos de 1,5-3 mm de comprimento, os frutos com 3 mericarpos acentuadamente dilatados e as sementes ecarunculadas.

\section{Nealchornea}

Nealchornea Huber, Bol. Mus. Paraense Hist. Nat. 7: 297. 1913.

Arvoretas a árvores dióicas, látex branco, adocicado. Ramos lenticelados, glabros. Folhas alternas, sem estípulas, nervuras peninérveas, ápice acuminado a caudado, base levemente cuneada ou aguda, margem crenada ou serrilhada. Inflorescência estaminada em panícula; flores estaminadas apétalas, amarelas, aromáticas, pedicelo delgado, cálice gamossépalo, lobos 4, quase indistintos, glabros; estames marrons, sésseis, anteras rimosas; inflorescência pistilada em racemo, flores 


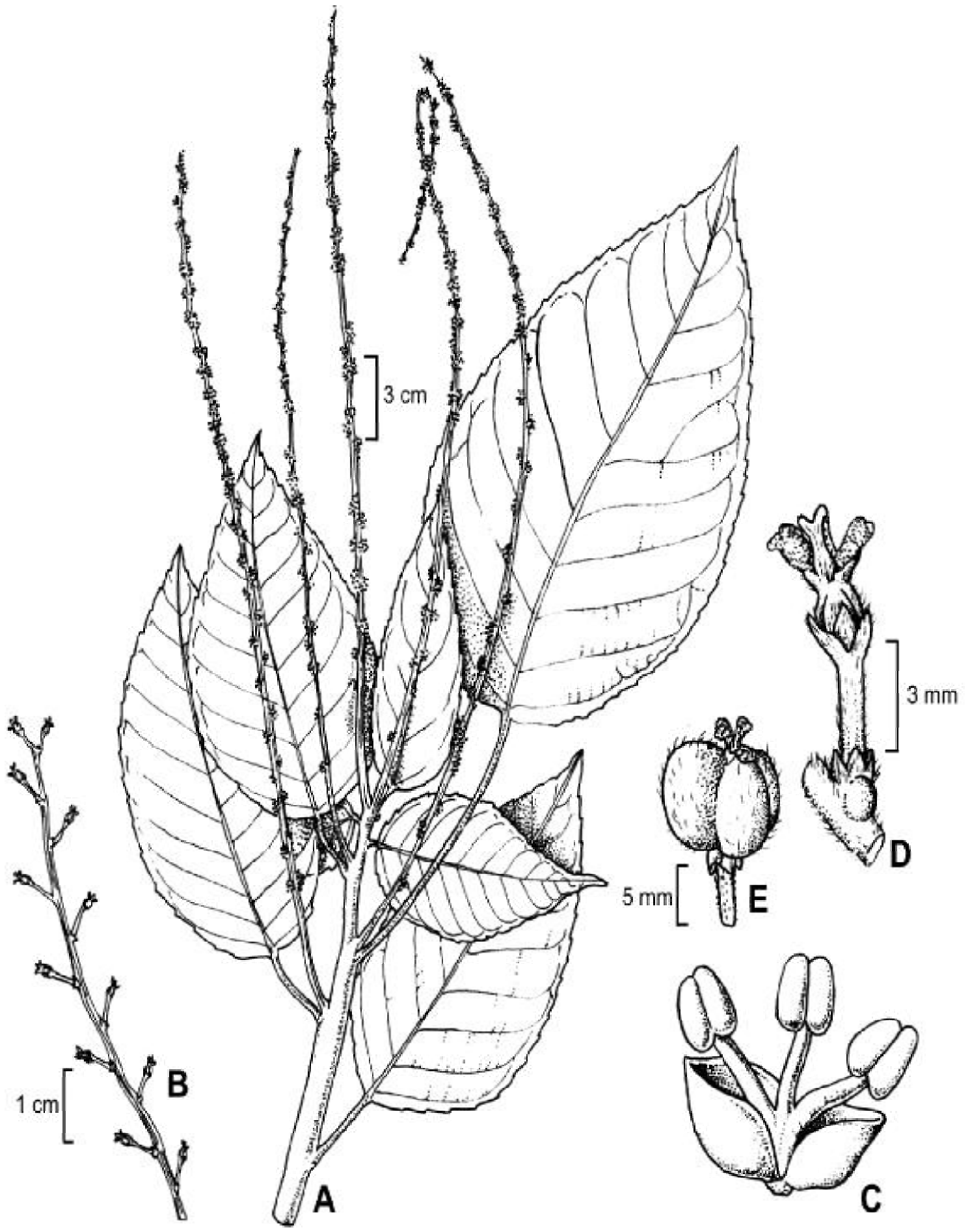

Figura 2 - Aparisthmium cordatum. A. Ramo com inflorescência estaminada. B. Inflorescência pistilada. C. Flor estaminada. D. Flor pistilada. E. Fruto. 
pistiladas apétalas, cálice gamossépalo, lobos 4, ovário com indumento ceroso ou velutino, estiletes 2. Frutos com 2 mericarpos, indeiscentes; sementes ecarunculadas.

Gênero representado por duas espécies neotropicais, sendo que na Reserva Ducke ocorre apenas a espécie-tipo, N. yapurensis.

3.1 Nealchornea yapurensis Huber, Bol. Mus. Paraense Hist. Nat. 7: 298. 1913. Fig. 3

Arvoretas a árvores 3-25 m alt., 10$70 \mathrm{~cm}$ DAP. Ramos levemente estriados. Folhas com pecíolo 2-15 cm compr., cilíndrico; limbo elíptico a elíptico-oblongo, 8-25×4-9 cm, cartáceo, ápice acuminado a caudado, base aguda, margem serrilhado-glandulosa, nervuras levemente proeminentes na face abaxial, impressas na adaxial. Inflorescências estaminadas $18-30 \mathrm{~cm}$ compr., flores isoladas, com pedicelo delgado $0,5-10 \mathrm{~mm}$ compr., subulados, pubescente a glabro, estames 10-17, constituídos por apenas uma antera; inflorescências pistiladas $10-30 \mathrm{~cm}$ compr., raque levemente estriada, pubescente, flores com pedicelo 3-4 mm compr., indumento ceroso, cálice com lobos quase indistintos; ovário 1-1,5 mm compr., $2 \mathrm{~mm}$ diâm., indumento ceroso, estiletes caducos, concrescidos até a metade, a parte apical aberta e recurvada. Frutos lobados, 1,5-2 cm compr., 1 cm diâm., às vezes com 1 mericarpo atrofiado, pubescentes.

Ocorre na Colômbia, Peru e Brasil (Amazonas, Acre, Pará e Rondônia).

Nome vulgar: gaivotinha-de-leite (Amazonas) 14.V.1995 (fl) Cordeiro, I. et al. 1548 (IAN INPA K MBM MG MO NY RB SP); 6.V.1988 (fl) Coêlho, D. 25-D (BMINPAK MGS SPUEC US); 14.IV.1994 (bt) Nascimento, J. R. et al. 506 (INPASP); 14.VI.1994 (fl) Ramos, J.F. \& Silva, C. F. da 2824 (G IAN INPA K MG SP SPF UUB); 30.VI.1993 (fl) Ribeiro, J. E. L. S. et al. 952 (FIAN INPA KMG SPUFMT); 12.VIII.1993 (fl) Ribeiro, J. E. L. S. et al. 1115 (B ICN INPA K MG S SP); 12.VIII.1993 (fl) Ribeiro, J. E. L. S. et al. 1122 (GH IAN INPA K MG NY SP); 14.VIII.1957 (fr) Rodrigues, W. 530 (INPA); 29.VIII.1957 (fr) Rodrigues, W. 575 (INPA); 24.VIII. 1963 (fl) Rodrigues, W. 5462 (INPA); 29.IV.1966 (fl) Rodrigues, W. \& Coêlho, D. 7732 (INPA); 4.V.1966 (fl) Rodrigues, W. \& Coêlho, D. 7811 (INPA); 24.X.1995 (fr) Souza, M. A. D. de et al. 129 (INPAKMBM MGMONYRBSPU); 22.VII.1994 (fr) Vicentini, A. et al. 642 (INPA MG SP); 24.IV.1995 (fl) Vicentini, A. \& Assunção, P. A. C. L.946 (MG SP); 4.IX.1995 (fl) Vicentini, A. et al. 1002 (COLIAN INPA KMGPUEFR SP VEN VIC).

Nealchornea yapurensis é uma espécie ictiotóxica e que se destaca por apresentar as folhas cartáceas com as margens serrilhadas, o ápice acuminado a caudado, as flores estaminadas evidenciando os estames, as flores pistiladas com 2 estiletes com a parte apical livre, aberta e recurvada, e o fruto com 2 mericarpos ferrugíneos. As flores estaminadas têm odor cítrico.

\section{Richeria}

Richeria Vahl, Eclog. Amer. 1: 30. 1797.

Arbustos a árvores, dióicos. Folhas simples, alternas, cartáceas a coriáceas. Inflorescências em espigas ou racemos, caulifloras, algumas vezes axilares, solitárias ou agrupadas. Flores monoclamídeas, as estaminadas sésseis, as pistiladas pediceladas; estames 3-6, livres, pistilódio presente; ovário 2-3-locular, pubescente ou glabro (tomentoso? em $R$. dressleri), 2 óvulos por lóculo, estiletes 2-3, inteiros ou bífidos. Fruto cápsula 2-3 mericarpos, tomentoso ou glabro; sementes 1 por lóculo (por aborto da outra).

Gênero cuja morfologia foliar é bastante variável, representado por duas espécies tropicais, sendo que na Reserva Ducke ocorrem ambas.

\section{Chave para as espécies de Richeria}

1. Ovário pubescente a glabro, fruto com 3 mericarpos, glabro; base da folha longamente cuneada; folhas ferrugíneas no material seco 1. $R$. grandis

1. Ovário tomentoso, fruto com 2 mericarpos, tomentoso-velutino; base da folha discretamente cuneada, folhas pardacentas no material seco 2. R. dressleri 


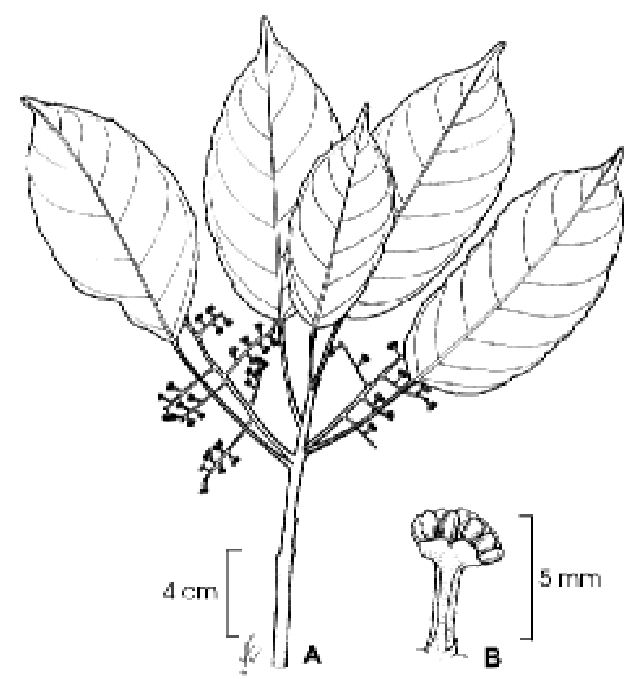

Figura 3 - Nealchornea yapurensis. A. Ramo com inflorescência estaminada. B. Flor estaminada.

4.1 Richeria grandis Vahl, Eclog. Amer. 1: 30. 1796. Fig. 4

Richeria australis Müll. Arg., Fl. bras. 11(2): 17. 1873

Richeria submembranacea Steyermark, Publ. Field. Mus. Nat. Hist. 17(5): 419. 1938.

Árvores 2-25 m alt., ca. $20 \mathrm{~cm}$ DAP. Ramos lisos ou com estriações, glabros. Folhas com pecíolo 0,5-3,5 cm compr., levemente canaliculado, glabro; limbo 5,5-16 ×2-9 cm, cartáceo a subcoriáceo, elíptico a elíptico-ovado, ápice agudo ou obtuso, base cuneada com 1 par de glândulas, face adaxial com nervuras planas à impressas, glabra, faces abaxial com nervuras proeminentes, glabra, margem levemente crenada a inteira, revoluta. Inflorescências estaminadas em espigas, axilares; flores dispostas em glomérulos multiflorais; flores estaminadas com cálice imbricado, 4-5 lobados, lobos ca. $1 \mathrm{~mm}$, lobos ovais, pubescentes externa e internamente, estames 5-6, 2-2,5 mm compr., filetes livres, anteras reniformes, pistilódio central cônico, pubescente, disco lobado; inflorescências pistiladas em racemos, $10-15 \mathrm{~cm}$ compr., flores pediceladas, 5-lobadas, lobos 1,5-2,0 mm compr., ovais, pubescentes interna e externamente, ovário pubescente a glabrescente, oval ou piriforme, ca. $1,5 \mathrm{~mm}$ compr., estiletes 2 , trífidos, disco anelado, pubescente. Fruto cápsula septífraga,

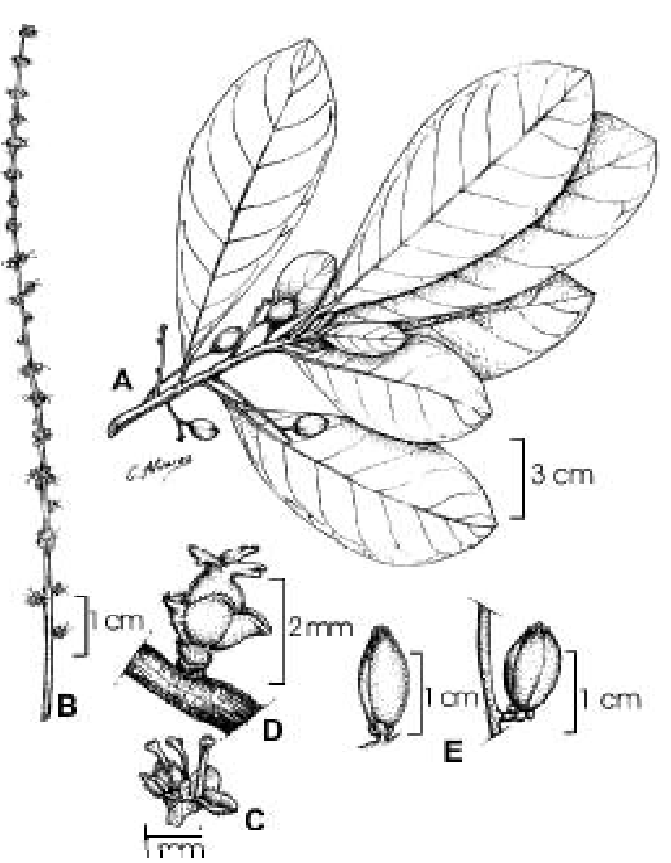

Figura 4 - Richeria grandis. A. Ramo com frutos. B. Inflorescência estaminada. C. Flor estaminada. D. Flor pistilada. E. Frutos.

piriforme, mericarpos 3 , pubescentes, tricomas curtos, 1-1,5 cm compr.; sementes elípticas, 2 por lóculo, 5-7 mm compr.

Espécie de ampla distribuição nas Antilhas e América do Sul (Colômbia, Venezuela, Guiana Francesa, Peru, Bolívia e Brasil - nas Regiões Norte, Nordeste, Centro-Oeste, Sudeste e Sul). 19.X.1994 (bt) Hopkins, M. J. G. et al. 1494 (G INPA K MG NY RB SP); 5.III.1958 (st) Pessoal de C. P. F. s.n. INPA6146 (INPA); 1.V.1966 (fr) Rodrigues, W. \& Coêlho, D. 7817 (INPA); 18.XII.1997 (fl) Souza, M. A. D. de \& Assunção, P. A. C. L. 504 (IAN INPA K MBM MGMO SPUUB).

4.2 Richeria dressleri G. L. Webster, Ann. Missouri Bot. Gard. 72: 1094. 1988.

Árvores ca. $15 \mathrm{~m}$ alt. Ramos levemente estriados. Folhas com pecíolo 1-2 cm compr., subulado, glabro; limbo $6-11 \times 3-5,5 \mathrm{~cm}$, coriáceo, elíptico, glabro, ápice agudo a obtuso, base discretamente cuneada, com um par de glândulas, margem espaçadamente ondulada, revoluta, face adaxial com nervuras planas, face abaxial com nervuras proeminentes. Inflorescência e flores não vistas. Infrutescências terminais, frutos isolados ou aos pares, raque 
estriada. Frutos cápsulas, mericarpos 2, 11,3 cm compr., 0,5-0,8 cm diâm., tomentosovelutino, com cálice lobado, persistente, estiletes 2, bífidos; sementes 1 por mericarpo, piramidais, ca. $3 \mathrm{~mm}$ compr.

Panamá, Costa Rica e Brasil (apenas no estado do Amazonas, Reserva Ducke). 15.VIII.1995 (fr) Assunção, P.A. C. L. et al. 216 (INPA KMBM MGMO NY RB SP).

Richeria dressleri está sendo colocada provisoriamente neste tratamento porque o material disponível para descrevê-la é pobre, havendo apenas frutos tomentoso-velutinos, com 2 mericarpos, o que nos levou à conclusão de que trata-se de $R$. dressleri. De acordo com Webster (1988), $R$. dressleri tem ovário tomentoso.

Possivelmente esta é a primeira ocorrência de R. dressleri na América do Sul.

\section{Pogonophora}

Pogonophora Miers ex Benth., Hooker's J. Bot. Kew Gard. Misc. 6: 372. 1854.

Gênero monotípico com ampla distribuição na América do Sul, especialmente no Brasil, onde ocorre nas Regiões Norte, Nordeste e Sudeste.

\subsection{Pogonophora schomburgkiana Miers ex} Benth., Hooker's J. Bot. Kew Gard. Misc. 6: 373. 1854. Fig. 5

Arbustos a árvores 1,5-25 m alt., dióicos. Ramos estriados, glabros, os mais jovens revestidos com tricomas malpiguiáceos. Folhas simples, alternas, com pecíolo 0,7-4 cm compr., pubescente, glabrescente, com pulvino apical, canaliculado; limbo 4,5-21×1,5-12 cm, coriáceo, oblongo, oblongo-elíptico, oblongolanceolado, glabro, ápice levemente acuminado ou agudo, base levemente cuneada a obtusa, margem inteira, levemente revoluta, face adaxial brilhosa, nervuras impressas; face abaxial opaca, nervuras proeminentes, especialmente a principal. Inflorescências em panículas, as estaminadas 1-6 cm compr., as pistiladas 3-6,5 cm compr., ambas com a raque serícea; flores estaminadas subsésseis, cálice imbricado, sépalas 5, livres, as externas
(2) com 1-2 mm compr., ovais a oblongas, as internas (3) com 1,5-2,5 mm compr., irregulares, orbicu-lares, pétalas 3-5 mm compr., 1-1,5 mm larg., oblongo-lanceoladas, denso-pilosas na face interna, externamente pubescentes, glabrescentes, estames 5, livres, 2,5-4,5 mm compr., ápice dos filetes pubescentes, dispostos externamente ao disco estaminal; anteras basefixas, rimosas, lanceoladas; disco 0,5-1 mm compr., pistilódio denso-piloso, 2-3 partido, disposto internamente ao disco intraestaminal; flores pistiladas curtopediceladas, cálice sépalas 5 , pétalas 5 , livres, imbricadas, 4-5 mm compr., 1-2 mm larg., lanceoladas, tricomas concentrados na parte central interna; ovário 3-locular, 1 óvulo por lóculo, tomentoso, assentado em disco delicado, de margem fimbriada, estiletes 3 , franjados, ca. 1,5 mm compr., papilosos. Fruto cápsula, mericarpos 3, comprimidos, oblongo a elípitico, 5-10 mm compr., 3,5-6 mm diâm; sementes ovais, 3,5-5 $\mathrm{mm}$ compr., negras, testa crustácea, carúncula amarela, orbicular.

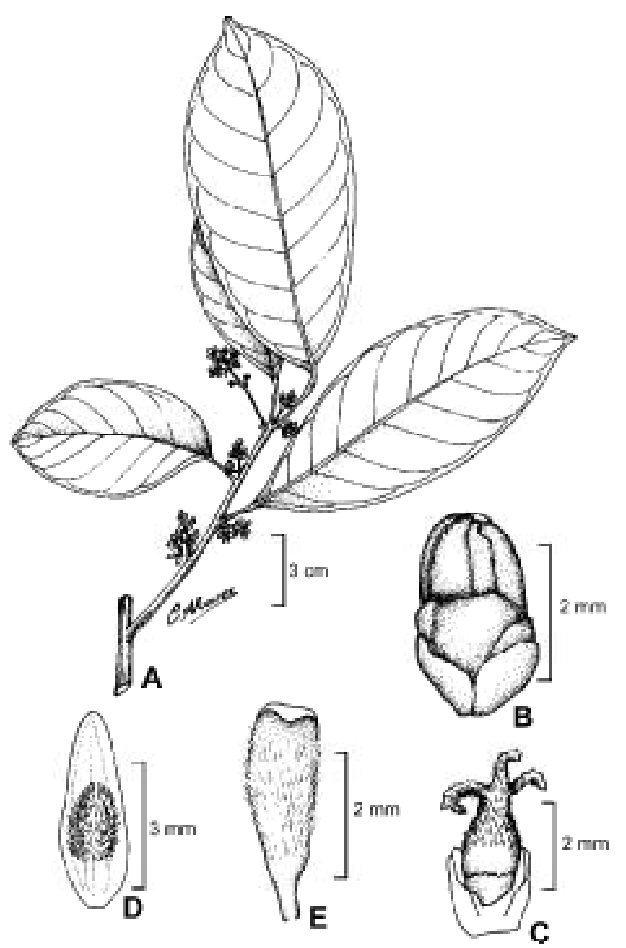

Figura 5 - Pogonophora schomburgkiana. A. Ramo com flores estaminadas. B. Botão da flor estaminada. C. Corte de uma flor pistilada. D. Pétala da flor pistilada. E. Pétala da flor estaminada. 
Espécie de ampla distribuição geográfica na América do Sul, abrangendo Venezuela, Guianas, Colômbia, Peru e Brasil.

Nomes vulgares: amarelinho, aracaporé, miratuarama (Amazonas).

9.I.1995 (fl) Assunção, P. A. C. L. 120 (IAN INPA K MGMO NYRB SP); 16.I.1995 (fl) Assunção, P.A. C. L. 143 (GINPA KMGSPSPF UUB US); 17.I.1995(fl) Assunção, P. A. C. L. 147 (BM INPA K MG PUEFR SPULMUPCB VEN); 7.II.1996(fr)Assunção, P. A. C. L. \& Silva, C. F. da 280 (COLINPA K MBM MGMO NY RB SP); 20.X.1995 (fl) Costa, M. A. S. \&Assunção, P.A. C. L. 403 (B FIAN INPAKMGSPUEC VIC); 24. II.1995 (fr) Nascimento, J. R. \& Pereira, E. da C. 762 (G INPA K MG R SP U UB VEN); 23.X.1995 (fl) Ribeiro, J. E. L. S. \& Pereira, E. da C. 1738(GHIAN ICN INPA K MG S SP UFMT); 5.XII.1963 (fl) Rodrigues, W. \& Coêlho, D. 5570 (INPA); 14.XII.1963 (fl) Rodrigues, W. \& Coêlho, D. 5598 (INPA); 31.I.1964 (fr) Rodrigues, W. \& Monteiro, O. P. 5700 (INPA); 21.V.1997 (fl) Sothers, C. A. \& Assunção, P. A. C. L. 997 (COL INPA K MBM MG SPW); 2.XII.1969 (fl) Souza, J. A. de 311 (INPA); 4.I.1993 (bt) Vicentini, A. \& Assunção, P.A. C. L. 384 (IAN INPAK MEXU R); 6.IV.1994 (fr) Vicentini, A. et al. 483 (BMINPA KMG SPUEC US VEN); 1.XI.1994 (fl) Vicentini, A. et al. 765 (INPAMG SP).

Pogonophora schomburgkiana é facilmente identificável por apresentar flores (especialmente as estaminadas) com pétalas denso-pilosas na face interna, os estames dispostos externamente ao disco e presença de pistilódio; os frutos apresentam os mericarpos comprimidos e as sementes são negras, pequenas (3,5-5 mm compr.), com carúncula orbicular, amarela.

\section{Anomalocalyx}

Anomalocalyx Ducke, Notizbl. Bot. Gart. Berlin Dahlem 11 (105): 344. 1932.

Gênero monotípico de ocorrência restrita e exclusiva na Amazônia brasileira.

6.1 Anomalocalyx uleanus (Pax \& K. Hoffm.) Ducke, Notiblz. Bot. Gart. Berlin Dahlem 11(105): 344. 1932. Fig. 6

Cunuria uleana Pax \& K. Hoffm., Pflanzenr. IV. 147, 14 (Heft 68): 51. 1919.

Árvores 2-40 m alt., $18-25 \mathrm{~cm}$ DAP, dióicas, sem látex. Ramos estriado-rugosos.
Folhas com pecíolo 1,5-13 cm compr., algumas vezes levemente canaliculado, com pulvino apical, glabro; limbo 5-30×3,5-13 cm, cartáceo a subcoriáceo, elíptico a elíptico-oblongo, glabro, margem inteira, ápice acuminado a caudado, base levemente aguda a cuneada; face adaxial com nervuras planas a levemente impressas, face abaxial com nervuras proeminentes, especialmente a principal, as secundárias anastomosando-se na margem. Inflorescências estaminadas em panículas, flores muitas vezes formando fascículos, 738 cm compr., glabras; flores amarelo-claras, aromáticas, com pedicelo 3-17 mm compr., espessados no ápice, cálice oculto na prefloração, levemente imbricado, 3-4-lobado no ápice, abrindo-se em 2(3) lobos na antese, lobos 3,55 mm compr., ovais, irregulares, membranáceos, glabros; pétalas 5, livres, 3-4,5 mm compr., obovais, ápice bilobado, pubescentes basalmente na face interna, estames 20-30, livres, eretos, 1-2 mm compr., fixados em receptáculo convexo, tomentoso, anteras biloculares, ovais, introrsas, disco estaminal anular, crenado, glabro. Inflorescências pistiladas em racemos, $0,5-13 \mathrm{~cm}$ compr., flores sempre de maior tamanho, glabras; flores pistiladas com pedicelo $10-25 \mathrm{~mm}$ compr., glabro, cálice irregular, coriáceo, 3(4)5-lobado na prefloração, abrindo-se em (2) 3 lobos na antese, 4-6 mm compr.; pétalas 5, oblongoelípticas, 5,5-7,5 mm compr., 4,5$5,5 \mathrm{~mm}$ larg., ovário subgloboso, estriado, glabro 3-locular, 2-3 mm compr., assentado em disco ondulado, glabro, estiletes 3, bífidos. Fruto cápsula septicida, loculicida, grande, ca. 2,5-4 cm diâm., deiscência explosiva, endocarpo lenhoso; sementes 3, elípticas a oblongoelípticas, opacas, levemente rugosas, salpicadas com minúsculos pontos e manchas marrons, ecarunculadas.

Espécie de distribuição restrita nos estados do Amapá e Amazonas.

Nomes vulgares: arataciú-preto, arataciurana e seringarana (Amazonas).

21.VIII.1997 (fl) Assunção, P. A. C. L. et al. 634 (INPA KMG SPUS); 11.IX.1987 (fr) Pruski, J. F. et al. 3219 (INPAMG RSPUEC); 30.IV.1995 (fr) Ribeiro, J. E. L. 


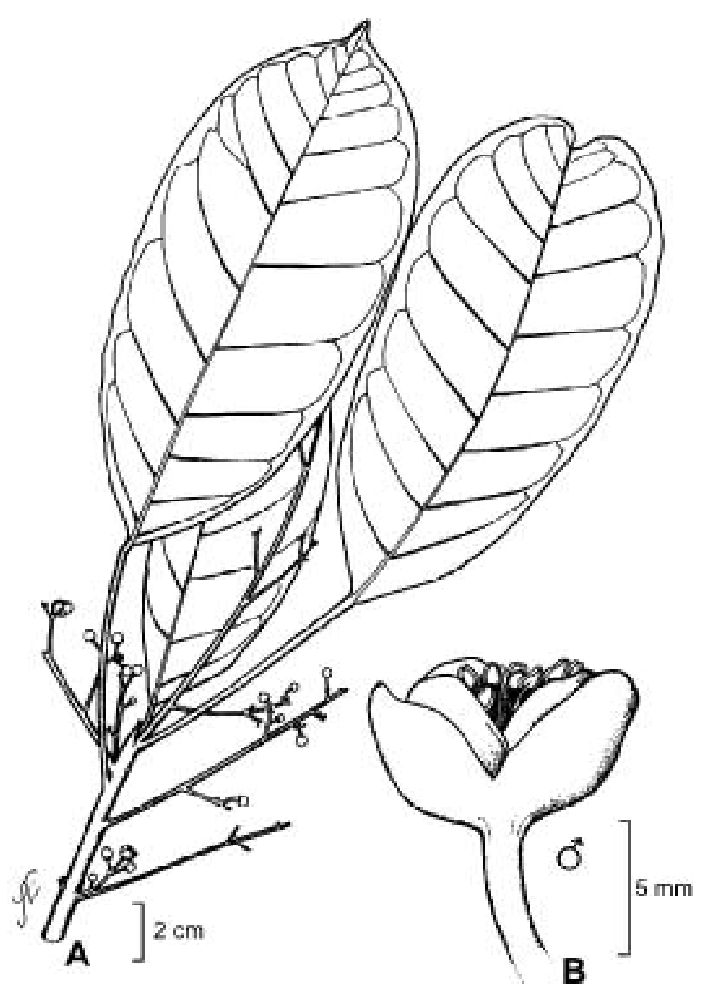

Figura 6 - Anomalocalyx uleanus. A. Ramo com inflorescência estaminada. B. Flor estaminada.

S. et al. 1627 (INPA K MBM MG MO NY RB SP US); 29.VIII. 1957 (fl) Rodrigues, W. 589 (INPA); 27.X.1994 (bt) Sothers, C. A. et al. 242 (BM G INPA K MBM MG SPUUEC); 13.IX.1994 (fl) Vicentini, A. et al. 683 (IAN INPA K MG MONY RB SPUB VEN); 10.II.1995 (fr) Vicentini, A. et al. 879 (G IAN INPAK MGSPUUB).

Anomalocalyx uleanus é facilmente identificável pelas folhas grandes, elípticas, glabras, com a face adaxial brilhosa e pecíolos que podem atingir até $13 \mathrm{~cm}$ de comprimento; o cálice da flor estaminada apresenta estrutura complexa, o que originou o nome do gênero; este cálice é 3-4-lobado na prefloração, levemente imbricado, mas na antese abre-se em 2(3) lobos; os estames variam de 20 a 30; as flores pistiladas são maiores e mais raras, apresentando o cálice com lobos irregulares, ovário glabro e 3 estiletes bífidos, perfazendo 6 ramificações; as sementes são um bom recurso para identificar a espécie na mata, têm forma oblonga-elíptica, sendo levemente rugosas, salpicadas com minúsculos pontos e manchas marrons, e sem carúncula.

\section{Pausandra}

Pausandra Radlk., Flora 53: 92, t. 2. 1870.

Árvores, arvoretas ou arbustos.

Folhas simples, alternas, peninérveas, pecíolo levemente canaliculado, com pulvino apical; limbo com a margem serrilhada, ápice agudo ou acuminado, base cuneada ou obtusa, com glândulas evidentes ou inconspícuas. Inflorescências axilares ou terminais, em espigas, com flores solitárias, aos pares, em tríades ou mais de 3; flores estaminadas em geral menores, as vezes inconspícuas, cálice (2)-3-5-lobados, irregular, imbricado, pubescente ou glabro; corola 5-lobada, concrescida acima da parte mediana ou apenas na base, lobos levemente emarginados ou revolutos, pubescentes ou glabros na face interna, estames (3-5) 6, às vezes um central, dispostos no interior de um disco; flores pistiladas maiores, cálice 3-5-lobados, pubescente, pétalas 5, livres ou levemente concrescidas na base ou até acima da parte mediana, pubescentes externamente, ovário séssil, 3-locular, um óvulo por lóculo. Fruto cápsula pubescente ou glabra, mericarpos dilatados; sementes 3, superfície marmórea, às vezes pouco nítida, carunculadas.

Gênero constituído de 6 a 7 espécies, distribuídas especialmente na América do Sul, sendo que apenas $P$. trianae Baill. também ocorre na América Central. Na Reserva Ducke ocorre apenas $P$. macropetala Ducke.

7.1 Pausandra macropetala Ducke, Arch. Jard. Bot. Rio de Janeiro 4: 114. 1925. Fig. 7

Árvores 4-10 m alt., dióicas, com resina amarelada, tornando-se avermelhada em contato com o ar. Ramos estriados, lenticelados, os mais jovens com indumento seríceo, tricomas malpiguiáceos, glabrescentes. Folhas com estípulas pequenas, triangulares, caducas, pubescentes; pecíolo geralmente curto, 0,5-1,5 $(-2,5) \mathrm{cm}$ compr., engrossado, rugoso, com coloração enegrecida peculiar nos ramos secos, limbo 12-34×3-9 cm, lanceolado a elíptico-lanceolado, subcoriáceo, às vezes cartáceos ou coriáceos, margem serrilhado- 
glandulosa, ápice acuminado, base cuneada com um par de glândulas arredondadas; face adaxial com nervura principal proeminente, as secundárias impressas, glabra; face abaxial com nervura principal proeminente, as secundárias levemente proeminentes, glabra. Inflorescências estaminadas com raque pubescente, axilares, $15-30 \mathrm{~cm}$ compr.; flores estaminadas amareladas, com cálice irregular, lobos 3(2), 2,5-4,0 mm compr., ovais, pubescentes externamente, corola 3,5-4,5 mm compr., concrescida até acima da parte mediana, com uma discreta faixa de tricomas na fauce, às vezes ausente, lobos arredondados, ápices discretamente emarginados, disco extra-estaminal plano ou ondulado, estames 6, epipétalos, 3-4,5 mm compr., an-teras oblongas, deiscência lateral; inflorescências pistiladas em espigas ou racemos espiciformes, 8-10 cm compr., raque pubescente, as flores isoladas; flores pistiladas mais raras, sésseis a subsésseis, cálice 3-lobados, ca. 3 mm compr., pubescente, corola concrescida até acima da parte mediana, ca. $6 \mathrm{~mm}$ compr., lobos 5, arredondados no ápice, pubescentes na face

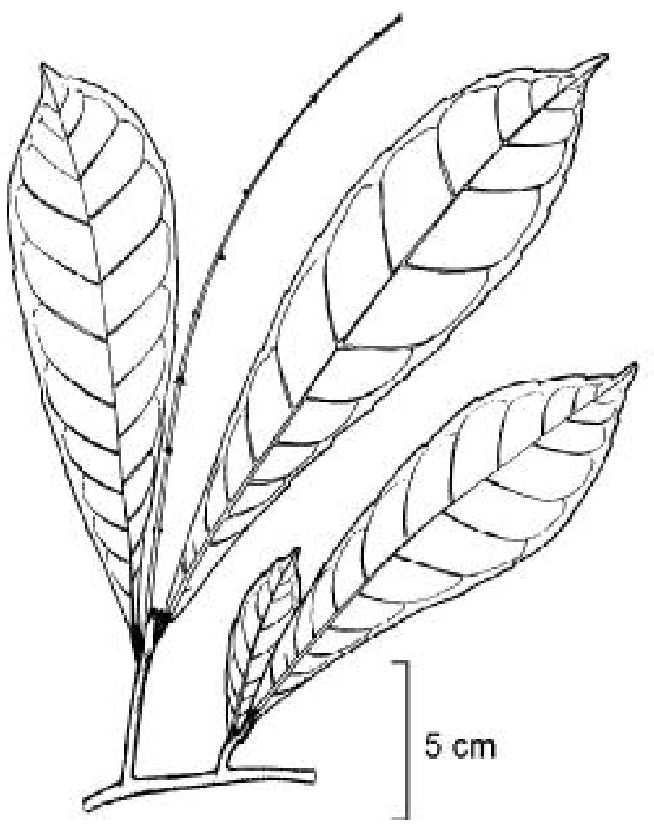

Figura 7 - Pausandra macropetala. Ramo com inflorescência espiciforme pistilada. interna, ovário com indumento seríceo, ca. 4 mm compr., oval, estiletes 3 , bífidos, curtos, espessados. Fruto cápsula septicidaloculicida, 10-13 mm compr., avermelhado na maturação; mericarpos 3, dilatados, pubescentes; sementes 3, marmóreas, 8-9 mm compr.

Ocorre com mais freqüência no estado do Amazonas, mas há registro de coleta no Pará (Santarém, Ducke RB 18000 e Oriximiná, Cid et al. 1804).

Nome vulgar: pau-sandra.

13.VII.1995 (fl) Costa, M. A. S. et al. 312 (G INPA K MBM MG SPUEC US); 11.V.1988 (fl) Coêlho, D. 40$D$ (IANINPAKMGNYRB SP); 6.IX.1966(fr) Prance, G. T. et al. 2194 (INPA); 6.VII.1993 (fl) Ribeiro, J. E. L. S. et al. 910 (IAN INPA KMG SPU); 20.IV.1961 (fl) Rodrigues, W. \& Coêlho, L. 2398 (INPA); 27.IV.1961 (fr) Rodrigues, W. \& Lima, J. 2436(INPA); 21.VII.1961 (fl) Rodrigues, W. \& Coêlho, D. 2983 (INPA); 24.XII.1963 (fl) Rodrigues, W. \& Cô̂lho, D. 5614 (INPA); 13.X.1995 (fr) Sothers, C. A. \& Pereira, E. da C. 629 (INPA SP); 26.IV.1994 (fl) Vicentini, A. et al. 488 (IAN INPA K MG MO SPUB).

Pausandra macropetala caracteriza-se principalmente por apresentar o pecíolo em

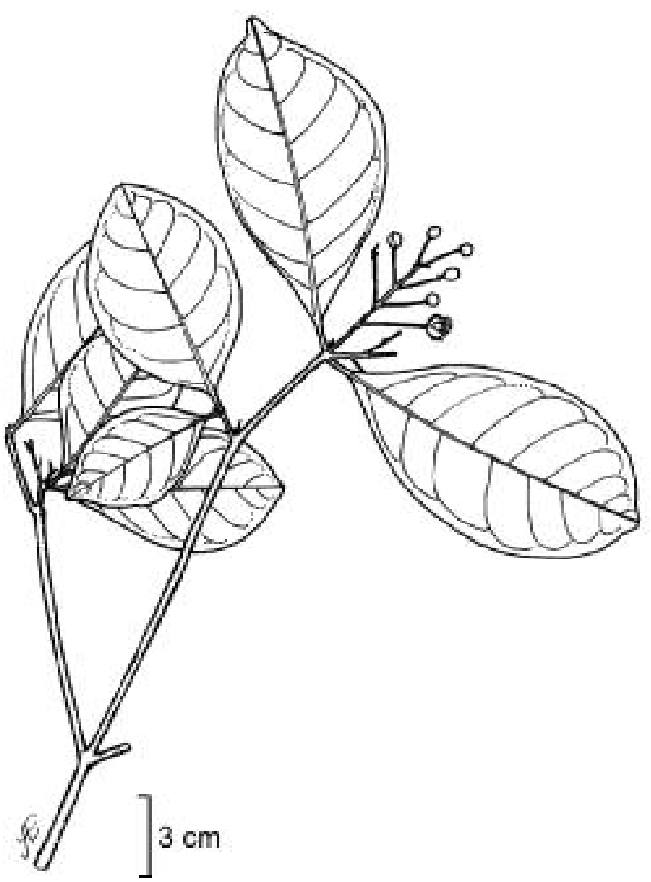

Figura 8 - Sandwithia guianensis. Ramo com inflorescência estaminada.

Rodriguésia 56 (86): 143-168. 2005 
geral curto, enegrecido no material seco, o limbo lanceolado a elíptico-lanceolado, com margens serrilhado-glandulosas, base cuneada, ápice acuminado, as inflorescências estaminadas frágeis, com as flores isoladas, aos pares ou em tríades, dispostas espaçadamente na raque.

\section{Sandwithia}

Sandwithia Lanj., Bull. Misc. Inform. Kew 4: 184.1932.

Árvores. Folhas simples, opostas ou subopostas, pecíolo canaliculado, pulvino apical; limbo cartáceo a subcoriáceo, nervuras peninérvias. Inflorescência estaminada em panícula ou fascículo, a pistilada em fascículo, ambas terminais; flores estaminadas pediceladas, com cálice 2-lobado, pétalas 3(4), imbricadas, estames longos ou curtos, numerosos, delgados, dobrados no botão; flores pistiladas pediceladas, cálice 3-lobado ou tubuloso, ondulado ou sépalas livres, pétalas 5, minúsculas, decíduas, ovário 3-locular, um óvulo por lóculo. Fruto cápsula, subgloboso, cônico, mericarpos 3; sementes carunculadas.

Gênero representado por duas espécies, com distribuição restrita à América do Sul. Na Reserva Ducke ocorre apenas S. guianensis, a espécie-tipo do gênero.

8.1 Sandwithia guianensis Lanj., Bull. Misc. Inform. Kew 4: 185. 1932. Fig. 8

Arvoretas ou árvores 2-24 m alt., 10$30 \mathrm{~cm}$ DAP. Folhas com pecíolo 1-4 cm compr., rugoso, glabro; limbo 4-25×15-10 cm, cartáceo, glabro, elíptico a elíptico-oval, base cuneada, ápice curto-acuminado ou agudo, margem inteira; face adaxial com nervuras planas, face abaxial com nervuras proeminentes. Inflorescências estaminadas $4-6 \mathrm{~cm}$ compr., glabras; flores estaminadas com pedicelo 5-10 mm (13-15 mm) compr., cálice com prefloração valvar, lobos 1,5-3 mm compr., pubescentes a glabros, pétalas 4,5-5 $\mathrm{mm}$ compr., ca. $2 \mathrm{~mm}$ larg., imbricadas, oblongas ou orbiculadas, margens ciliadas; estames 5$10 \mathrm{~mm}$ compr., receptáculo do androceu pubescente, anteras basifixas; inflorescências pistiladas em fascículos, $2-3 \mathrm{~cm}$ compr., flores pistiladas com pedicelo 5-8 mm compr., cálice 3-lobado ou tubuloso, pétalas 5 (6), 0,5-1 mm compr., inconspícuas, lanceoladas a obovais, caducas, denso-pubescentes, ovário 1-2,5 mm compr., denso-piloso, estiletes 3, bífidos. Frutos 1,2-1,5 cm compr.; sementes ovais, 8-12 mm compr., quilhadas.

Venezuela, Guiana e Brasil (estados do Amapá e Amazonas).

Nome vulgar: "urucurana-branca" (Amazonas). 17.VI.1958(fl) Coêlho, L. 17(INPA); 6.VI.1993 (fl) Ribeiro, J. E. L. S. et al. 889 (BM G INPA K MBM MG SPU UEC UFMT US); 18.IX.1995 (fl) Vicentini, A. \& Silva, C. F. da 1028 (INPA K MG MO NY RB SPUB). Material adicional: Amapá, Macapá, 5.X.1985 (fl fr), Rabelo et al. 3198 (MG).

Sandwithia guianensis é uma espécie inconfundível por apresentar as folhas elípticas a elíptico-ovais, nervuras muitas vezes formando arcos na margem, as inflorescências estaminadas muito delicadas em panículas, às vezes geminadas, geralmente no ápice dos ramos, as flores com pedicelos lineares e numerosos estames com filetes finíssimos.

\section{Conceveiba}

Conceveiba Aubl., Hist. Pl. Guiane 2: 923. 1775.

Gavarretia Baill., Adansonia I: 185, t. 7. 1860.

Conceveibastrum (Müll. Arg.) Pax \& K. Hoffm., Pflanzenr. IV 147. 17 (Heft 85): 217. 1914.

Arbustos, arvoretas a árvores. Folhas simples, alternas, estípulas incospícuas a grandes e vistosas, pecíolo canaliculado, raro inteiro; limbo cartáceo a coriáceo, nervuras peninérvias a palmatinérvias. Inflorescências estaminadas em panículas ou corimbos, as pistiladas em racemos; flores estaminadas monoclamídeas, subsésseis, sésseis a pedi-celadas, bractéolas 3 por flor, cálice gamossépalo, valvar, estames 8-15, concrescidos pelas bases, dispostos externamente a um grupo de 3-35 estaminódios; flores pistiladas monoclamídeas, sésseis a 
pediceladas, bractéolas 3 por flor, cálice livre, sépalas valvares, base glandulosa, ovário 3locular, estiletes 3 , livres a concrescidos na base. Fruto cápsula septicida, mericarpos 3; sementes pintalgadas, carunculadas.
Gênero representado por 13 espécies, sendo duas da África, uma da América Central e 10 da América do Sul. Na Reserva Ducke ocorrem Conceveiba guianensis, espécietipo do gênero e de ampla distribuição na Amazônia, e C. martiana Baill.

\section{Chave para as espécies de Conceveiba na Reserva Ducke}

1. Folhas peninérveas, estípulas ausentes; limbos elíptico-ovais a elíptico-lanceolados, bases arredondadas a levemente cuneadas; inflorescência estaminada em panícula; fruto acentuadamente trígono, com quilhas ou alas acentuadas .... 1. C. guianensis

1. Folhas palmatinérveas, estípulas conspícuas, lanceolado-sacciformes; limbos orbiculares a elíptico-orbiculares, bases profundamente cordadas; inflorescência estaminada em corimbo; fruto subgloboso, as vezes levemente trígono ......

2. C. martiana

9.1 Conceveiba guianensis Aubl., Hist. Fl.Guiane 2: 924, t. 353. 1775. Fig. 9

Arbustos, arvoretas ou árvores, 3$20 \mathrm{~m}$ alt., 10-30-(-80) cm DAP. Folhas peninérveas com pecíolo $1,5-8 \mathrm{~cm}$ compr., pulverulentos a pubescentes; limbo 5-35×3,5$15(-21) \mathrm{cm}$, cartáceo a coriáceo, elíptico-oval a elíptico-lanceolado, face adaxial pubescente na nervura principal ou glabra, face abaxial pubescente, tricomas estrelados, domácias de tricomas estrelados na junção da nervura principal com as secundárias, base arredondada a levemente cuneada, ápice acuminado a caudado. Inflorescências estaminadas em panículas, terminais, raro axilares, 12-26 cm compr., flores dispostas em glomérulos; flores estaminadas com pedicelo 0,5-1,5 mm compr., cálice gamossépalo, valvar, lobos 3, ovais, côncavos, glabros, 1-2 mm compr., estames 8-12, sendo 3-5 menores, 57 maiores, 0,5-1 mm compr., dispos-tos externamente a um feixe de 6-12 estaminódios em geral dobrados, plicados, 2,5-4 mm compr., às vezes com rudimento de anteras; inflorescências pistiladas em racemos, 6$18 \mathrm{~cm}$ compr., axilares ou terminais, flores isoladas, raro aos pares; flores pistiladas com pedicelo 2,5-5 mm compr., cálice dialissépalo, glândulas 4-6 na base, sépalas 4-6(8), lanceoladas, pubescentes externamente, 23 mm compr., 0,5-1 mm larg., ovário elíptico, levemente trígono, tomentoso, 2,5-4 mm diâm., estiletes eretos ou dobrados, 1,5-5 mm compr., grossos, bífidos, concrescidos na base, face interna denso-papilosa. Frutos trígonos, com 3 quilhas ou alas acentuadas, 1,5-2 cm diâm., pubescentes; sementes 3 , naviculares, 1 $1,5 \mathrm{~cm}$ diâm.

Colômbia, Venezuela, Guianas, Peru, Brasil (Amazônia) e Bolívia.

Nomes vulgares: arara-seringa (Amazonas), arraeira (Amapá e Pará), azedinho (Mato Grosso), urucurana (Pará).

6.XII.1963 (fr) Rodrigues, W. \& Coêlho, D. 5576 (INPA); 14.XII.1963(fr) Rodrigues, W.\& Coêlho, D. 5597 (INPA); 20.XII.1963(fr) Rodrigues, W.\& Coêlho, D. 5637 (INPA); 4.I.1964(fr) Rodrigues, W.\& Monteiro, O. P. 5662 (INPA); 26.I.1966 (fr) Rodrigues, W. \& Monteiro, O. P. 7406 (INPA); 7.XI.1994(fr) Sothers, C.A. et al. 264(BM GIAN INPAK MGSPSPFUECUS); 7.XII.1994 (fr) Vicentini, A. \& Pereira, E. da C. 786(IANINPAK MBM MGMO SPUUB); 20.X.1995 (fl) Vicentini, A. \& Pereira, E. daC. 1100 (IANINPAKMBMMGMOSPUUB);3.XI.1995

(fl) Vicentini, A. \& Silva, C. F. da 1127(INPA KMGNY RBSP); 12.XII.1995(fr) Vicentini, A. \& Pereira, E. daC. 1162 (IANINPAKMGNYRBSP).

Conceveiba guianensis é uma espécie facilmente reconhecível por apresentar folhas com a face adaxial brilhosa, nervação peninérvea, estames 8-12, dispostos externamente a um feixe de 6-12 estaminódios, flores com glândulas na base do cálice e frutos em geral acentuadamente trígonos. 


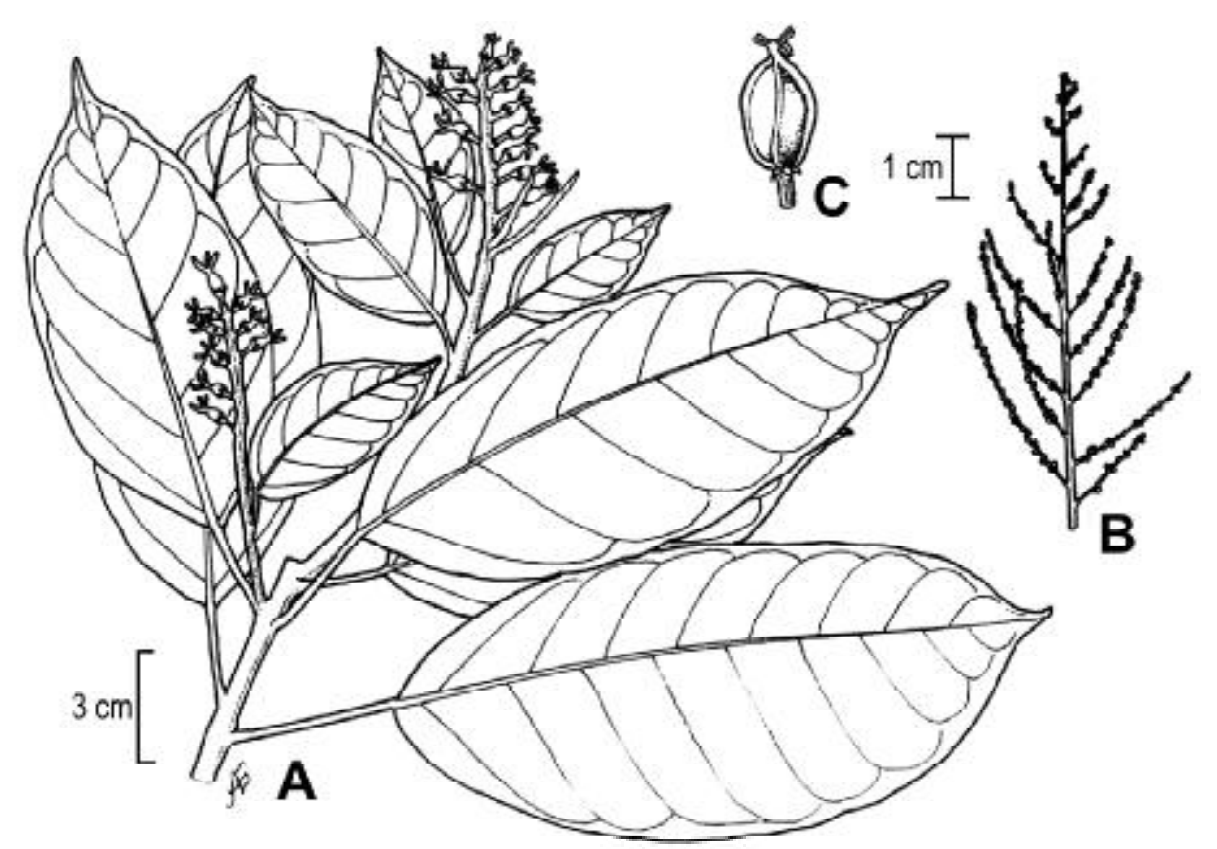

Figura 9 - Conceveiba guianensis. A. Ramo com inflorescência pistilada. B. Inflorescência estaminada. C. Fruto.

9.2 Conceveiba martiana Baill., Adansonia 5: 221. 1864. Fig. 10

Conceveibastrum martianum (Baill.) Pax \& K. Hoffm., Pflanzenr. IV. 147. 7 (Heft 63): 217. 1914.

Arbustos ou árvores 3-30 m alt., 10$30 \mathrm{~cm}$ DAP. Folhas palmatinérveas com pecíolo 3,5-25 cm compr., pubescente a pulverulento, estípulas lanceolado-sacciformes, côncavas, estriadas, $1,5-5 \mathrm{~cm}$ compr., pubescentes; limbo 10-32×7,5-24 cm, coriáceo, orbicular a elíptico-orbicular, face adaxial pubescente nas nervuras, face abaxial pulverulenta a pubescente, tricomas estrelados, domácias presentes, base profundamente cordada, trinervada, ápice obtuso a agudo. Inflorescências estaminadas em corimbos, terminais, 15$32 \mathrm{~cm}$ compr., flores dispostas em glomérulos; flores estaminadas com pedicelo $0,5-1,5 \mathrm{~mm}$ compr., cálice gamossépalo, valvar, lobos 3-4, ovais, côncavos, pubescentes, 2-3,5 mm compr., estames 12 , sendo 3-4 menores, 8-9 maiores, 0,5-2 $\mathrm{mm}$ compr., dispostos externamente a um conjunto de 15-35 estaminódios livres, em geral dobrados, plicados, 2,5-4 mm compr., às vezes com rudimentos de anteras; inflorescências pistiladas em racemos, terminais, $10-30 \mathrm{~cm}$ compr., flores isoladas; flores pistiladas com pedicelo 7-9 mm compr., tomentoso; cálice dialissépalo, glanduloso na base, sépalas 7-9, imbricadas, 4-5 ex-ternas, 3-4 internas, sagitadas, tomentosas, 2,5-3,5 mm compr., ovário subgloboso a globoso, levemente trígono, tomentoso, 3-4 mm diâm., estiletes eretos, 7-9 mm compr., bífidos, concrescidos na base, face interna denso-papilosa. Frutos subglobosos, levemente trígonos ou não, 11,8 cm diâm., pulverulentos; sementes ovais, levemente quilhadas ventralmente.

Colômbia, Venezuela, Guiana Francesa, Peru, Brasil (Amapá, Pará e Amazonas) e Bolívia.

Nomes vulgares: arraieira-branca (Pará), Sacha zapote (Peru), palo-de-mataguare (Venezuela).

15.IX.1987 (fl) Pruski, J. F. et al. 3265 (INPA MG SP); 22.XII.1963 (fl) Rodrigues, W. \& Coêlho, D. 5632 (INPA); 31. XII.1963 (fr) Rodrigues, W. \& 
Monteiro, O. P. 5649 (INPA); 10.X.1995 (fl) Sothers, C. A. \& Pereira, E. da C. 610 (G IAN INPA K MG SP SPF U UB); 12.X.1995 (fl) Sothers, C. A. \& Pereira, E. da C. 623 (IAN INPA K MG MO NY RB SP); 22.IX.1994 (fl) Vicentini, A. et al. 711 (INPA MG SP); 1.XI.1994 (fr) Vicentini, A. et al. 772 (INPA KMG MONYRB SPUUB); 3.XI.1995 (fl) Vicentini, A. \& Silva, C. F. da 1125 (BM INPA K MBM MG SPUS).

Conceveiba martiana destaca-se por apresentar folhas grandes, em geral orbiculares, com as bases trinervadas e acentuadamente cordadas, as estípulas bastante evidentes, grandes e que servem como formicários; além disso, apresenta inflorescências estaminadas em corimbos e frutos subglobosos.

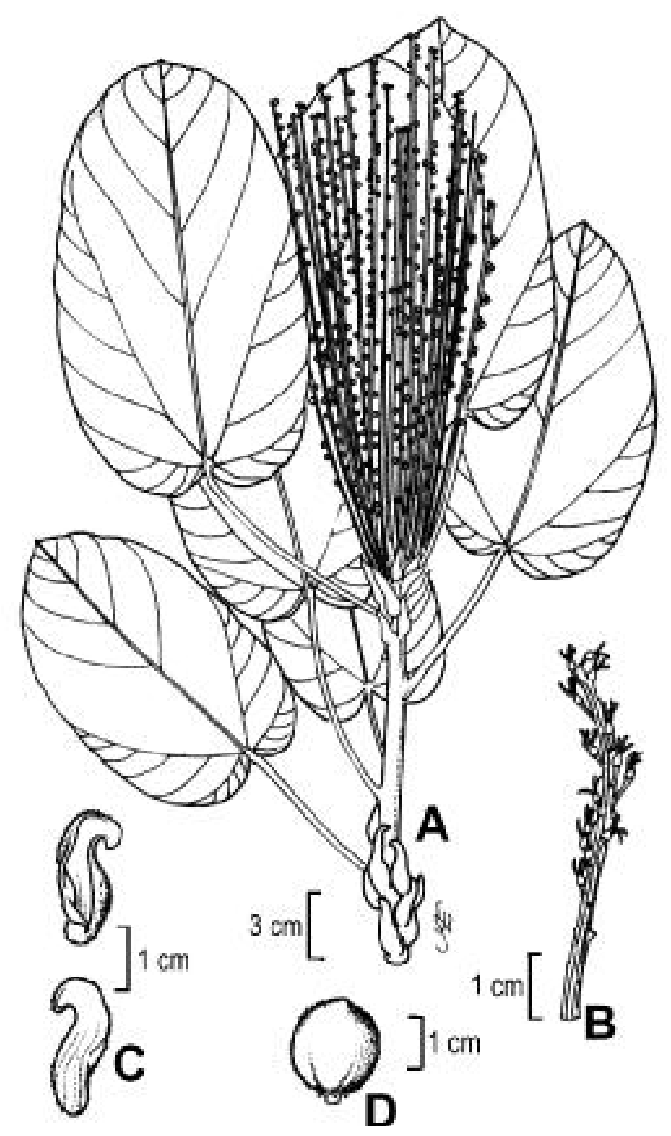

Figura10 - Conceveiba martiana. A. Ramo com inflorescência estaminada. B. Inflorescência pistilada. C. Estípulas. D. Fruto.

\section{Alchorneopsis}

Alchorneopsis, Müll. Arg., Linnaea 34: 156. 1865

Árvores dióicas. Folhas alternas, trinervadas a partir da base, sem estípulas, intra-estaminal ou extra-estaminal, glabras; margem inteira. Inflorescências estaminadas em racemos espiciformes, axilares, às vezes terminais; inflorescências pistiladas em racemos espiciformes; flores monoclamídeas, as estaminadas aos pares, em tríades ou em glomérulos com poucas flores; flores estaminadas com cálice gamossépalo, valvar, estames 5-6, livres, rodeados por um tufo de tricomas simples, anteras ovais, pistilódio trímero presente; flores pistiladas isoladas com cálice dialissépalo, sépalas pubescentes, ovário 3-locular, estiletes 3, curtos, livres. Fruto cápsula, sementes ecarunculadas.

Gênero representado por três espécies, mas que provavelmente poderão ser reduzidas para apenas uma (Alchorneopsis floribunda), com distribuição geográfica exclusivamente neotropical.

10.1 Alchorneopsis floribunda (Benth.) Müll. Arg., Linnaea 34: 156. 1865. Fig. 11

Alchornea glandulosa var. floribunda Benth., Hooker's J. Bot. Kew Gard. Misc. 6: 331. 1854

Árvores 6-28 m de compr., $22-35 \mathrm{~cm}$ DAP. Ramos com estriações, lenticelados, glabros. Folhas palmatinérveas, pecíolo 2-3 cm compr., canaliculado, glabro; limbo 6,5-16×46,5 cm larg., elíptico, subcoriáceo a coriáceo, ápice acuminado, base levemente cuneada com um par de glândulas mais evidentes na face abaxial, glabro; face abaxial com nervuras proeminentes, evidenciando a principal, duas secundárias a partir da base, 1 a 2 acima da parte mediana da lâmina; face adaxial com nervuras planas e levemente proeminentes, com rede de nervuras terciárias mais evidentes que na face abaxial. Inflorescências estaminadas isoladas ou geminadas, $6-12 \mathrm{~cm}$ compr., a raque tomentosa; flores estaminadas com pedicelo ca. $1 \mathrm{~mm}$ compr., denso- 
pubescente, cálice com lobos 3-4, elípticos, 11,5 mm compr., pubescentes, tricomas simples; estames 2,5 mm compr., rodeados por um tufo de tricomas simples, anteras ovais, pistilódio trímero, glabro, disposto no centro do androceu. Inflorescências pistiladas isoladas ou geminadas, axilares, $6-10 \mathrm{~cm}$ compr., a raque tomentosa; flores pistiladas com 3 bractéolas na base, pedicelo ca. $1 \mathrm{~mm}$ compr., denso-pubescente; sépalas 4 , ovais, 0,5-1 mm compr., pubescentes, tricomas simples; ovário piriforme, 3-locular, ca. 1,5 mm compr., tomentoso, rodeado por disco piloso, estiletes 3, curtos, glabros. Frutos (depauperados nas amostras analisadas) com 3 mericarpos comprimidos, pubescentes; sementes muricadas, ca. 2,5 mm compr.

Porto Rico, Panamá, Colômbia, Guianas, Peru e Brasil (Amapá, Amazonas, Acre, Pará e Roraima).

29.XI.1995 (fl) Assunção, P. A. C. L. \& Pereira, E. da C. 257 (BM G IAN INPA K MBM MG SP US); 5.V.1995 (fl) Cordeiro, I. et al. 1538 (COL INPA K MG NY SP); 13.XII.1995 (fl) Nascimento, J. R. et al. 687 (IAN INPA K MG MO R SP U VEN);

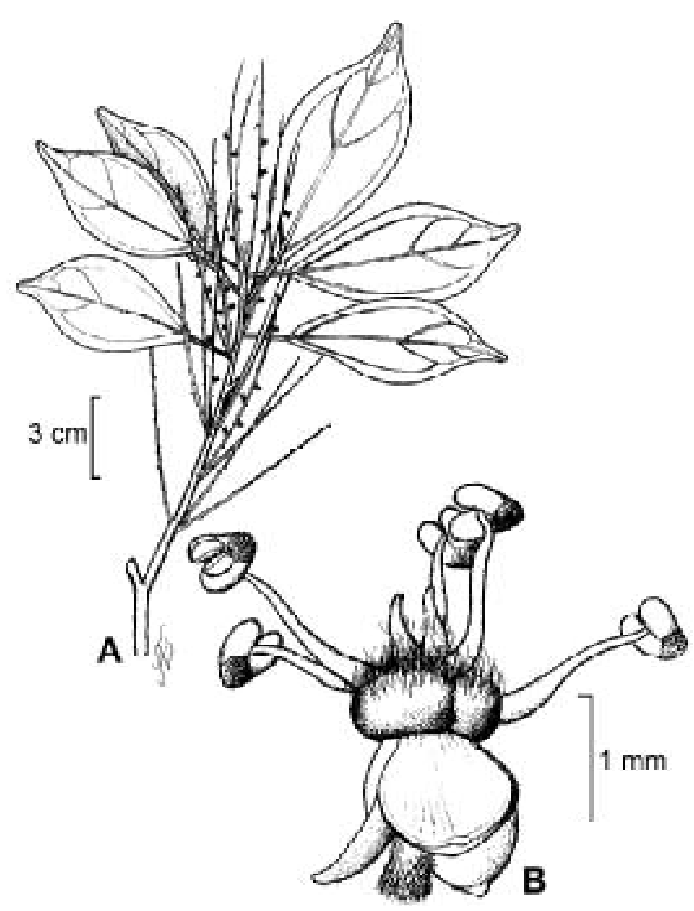

Figura 11 - Alchorneopsis floribunda. A. Ramo com inflorescência estaminada. B. Flor estaminada.
25.V.1961 (fl) Rodrigues, W. \& Lima, J. 2650 (INPA). Material adicional: Barcelos, rio Solimões, 26.IX. 1968 (fl), Silva, M. 1968 (MG); rio Negro, Jauaperi, 25.II.1977 (fl), Santos, M. R. 105 (INPA MG NY); Axinim, along rio Abacaxis, 8.VII.1983 (fl), Zarucchi, J. et al. 2991 (INPA MG).

Alchorneopsis floribunda é uma árvore grande, com raízes tabulares na base, ritidoma fissurado, com seiva escassa e translúcida saindo do caule, quando este é cortado. É facilmente identificada por apresentar as folhas trinervadas a partir da base, as inflorescências delicadas em racemos espiciformes, os estames rodeados por um tufo de tricomas e o ovário piriforme com 3 estiletes curtos; as flores estaminadas apresentam pistilódio trímero no centro do androceu.

\section{Adenophaedra}

Adenophaedra (Müll. Arg.) Müll. Arg., in Mart. Fl. bras. 11(2): 385. 1874.

Árvores ou arbustos dióicos. Ramos com tricomas simples ou glabros. Folhas alternas, peninérveas, estípulas glandulosas presentes. Inflorescências estaminadas em racemos espiciformes ou em panículos, as pistiladas em racemos ou algumas vezes em panículas, brácteas envolvendo 1 flor pistilada ou várias estaminadas. Flores estaminadas pediceladas, cálice 3-lobado, pétalas ausentes, estames 2-5, opostos aos lobos do cálice, livre, filetes curtos, anteras com conectivo alargado, deiscência introrsa ou longitudinal, pistilódio ausente; flores pistiladas subsésseis a pediceladas, cálice 6-lobado, lobos imbricados, pétalas ausentes, disco 3-lobado presente, ovário 3-carpelar, óvulos 1 por lóculo, estiletes curtos ou estigmas sésseis. Fruto cápsula 3lobado; sementes arredondadas, ecarunculados.

Gênero representado por três espécies, distribuído desde o Panamá e Costa Rica, alcançando a América do Sul através da Venezuela, Guianas, Brasil (Amazonas, Ceará e Bahia) e Bolívia (Pando). Ainda é mal coletado na Amazônia, possivelmente devido a sua raridade nas florestas. Na Reserva Ducke, ocorre apenas Adenophaedra grandifolia. 
11.1 Adenophaedra grandifolia (K1.) Müll. Arg., in Mart. Fl. bras. 11(2): 386. 1874. Fig. 12

Tragia grandifolia Kl., London J. Bot. 2: 46.1843

Arvoretas finas 6-7 m alt., ca. $5 \mathrm{~cm}$ DAP. Ramos com discretas estriações, glabros, com muitos líquens e musgos. Folhas com pecíolo 0,5-1 cm compr., estriado, tomentoso; limbo oboval-espatulado, raro oboval-lanceolado, 12-19×3,5-4 cm, cartáceo ou subcoriáceo, ápice acuminado, às vezes caudado, base longamente cuneada, margem serrilhada; face abaxial com nervuras proeminentes, indumento de tricomas simples mais concentrado nas nervuras principal e secundárias; face adaxial com nervuras planas a levemente proeminentes, esparsamente pubescentes especialmente na nervura central. Inflorescências estaminadas em racemos espiciformes, 15-23 cm compr., flores dispostas em glomérulos (de 5 a 12 flores), envolvidos por 1 bractéola, raque pubescente; flores estaminadas com pedicelo $1 \mathrm{~mm}$ compr., glabro; sépalas 3, elípticas, $1 \mathrm{~mm}$ compr., glabras; estames 2(3), concrescidos pelas bases, 0,5-1 mm compr., filetes grossos, anteras globosas. Inflorescências pistiladas em racemos, as flores isoladas, a raque

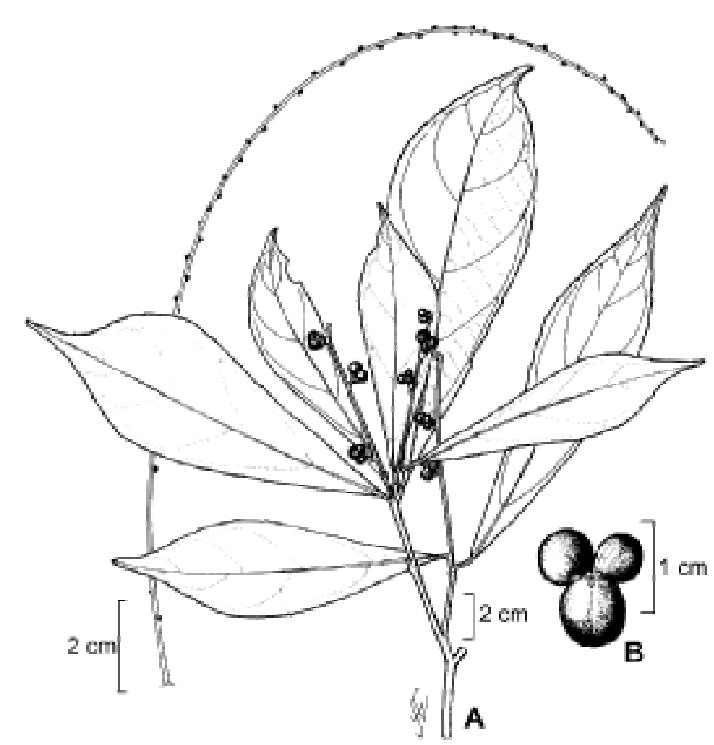

Figura 12. Adenophaedra grandifolia. A. Ramo com frutos. B. Fruto em detalhe. pubescente; flores pistiladas (analisadas em mal estado) com pedicelo ca. $2 \mathrm{~mm}$ compr., tomentoso, sépalas 6 , imbricadas, sagitadas, 2 a 3 internas, 3 externas, 1,5-2 mm compr., pubescentes, ovário 3-locular, 3-lobado, pubescente, 2-2,5 $\mathrm{mm}$ compr., estigmas sésseis. Frutos com 3 mericarpos bem acentuados, dilatados, ca. $1 \mathrm{~cm}$ diâm., estigmas sésseis, persistentes.

Panamá, Costa Rica e Brasil (estado do Amazonas).

26.IX.1997 (fl) Ribeiro, J. E. L. S. \& Assunção, P.A. C. L. 1922 (INPAKMGMONYRB SPUUB); 26.IX.1997

(fr) Ribeiro, J.E.L.S. \& Assunção, P. A. C. L. 1923 (INPA K MG MO NYRB SPUUB).

Adenophaedra grandifolia é uma arvoreta rara na Reserva, tendo sido coletada apenas às margens de um igarapé. Pode ser identificada facilmente pelas folhas obovalespatuladas, com as bases longamente cuneadas; as inflorescências estaminadas são delicadas, em racemos espiciformes, com flores bastante diminutas; os frutos apresentam os mericarpos dilatados, bem acentuados, com os estigmas persistentes; apresenta resina avermelhada no caule, similar àquela encontrada em Pausandra macropetala.

\section{Croton}

Croton L., Sp. Pl. 2: 1004. 1753.

Árvores, arbustos, ervas ou lianas, monóicos ou dióicos. Ramos geralmente com resina, indumento de tricomas estrelados ou escamosos (lepidotos). Folhas alternas, peninérveas ou palmatinérveas, pecíolo geralmente com glândulas no ápice; estípulas presentes, às vezes inconspícuas, limbo inteiro ou lobado, margem inteira ou às vezes serrilhada. Inflorescências unissexuadas em racemos ou racemos espiciformes, as vezes em panículas, terminais ou axilares; inflorescências bissexuadas em racemos, com as flores pistiladas na base, geralmente solitárias, às vezes, reuni-das com as estaminadas, as estaminadas geralmente agrupadas, em maior quantidade, no restante 
da raque. Flores estaminadas diclamídeas com cálice 4-6 lobado, lobos valvares, pétalas geralmente 5 (raramente ausentes); estames livres, filamentos dobrados no botão; flores pistiladas geralmente com cálice 5-7 lobado, lobos valvares, pétalas 5, geralmente reduzidas, ovário 3-carpelar, ovário 1 por lóculo, estiletes geralmente livres, bífidos ou bipartidos. Fruto cápsula; sementes carunculadas ou ecarunculadas.
Gênero bastante complexo, representado por cerca de 800 espécies, a maioria distribuída nas Américas, necessitando de criteriosa revisão, especialmente das espécies da Amazônia. As espécies Croton lobatus e $C$. glandulosas são invasoras, portanto não são espontâneas da Reserva Ducke e em razão disso deixam de ser incluídas no presente tratamento.

\section{Chave para as espécies de Croton na Reserva Ducke}

1. Folhas com nervuras peninérveas, paralelas entre si e pouco perceptíveis; face abaxial prateada ou pardacenta, brilhosa no material seco; limbo com tricomas escamosos (lepidotos); filetes com tricomas vilosos; cálice de flor pistilada com tricomas escamosos na face externa, e tricomas estrelados, pluriramificados, na face interna ..................................... 1. $C$. matourensis

1. Folhas com nervuras palmatinérveas, bem evidentes; face abaxial sem a característica acima citada; limbo com tricomas estrelados; filetes glabros; cálice de flor pistilada com tricomas estrelados na face externa, glabro na face interna 2. C. sampatik

12.1 Croton matourensis Aubl., Hist. Pl. Guiane 2: 879. 1775. Fig. 13

Croton matourensis var. benthamianus

Müll. Arg., Linnaea. 34: 95. 1865.

Croton benthamianus (Müll. Arg.)

Lanj., Euphorb. of Surinam, p.17. 1931.

Croton lanjouwensis Jabl., Mem. New York Bot. Gard. 12: 158. 1965.

Árvores 15-20 m alt., ca. $35 \mathrm{~cm}$ DAP, monóicas. Ramos cobertos por tricomas escamosos. Folhas com pecíolo 1,0-2,0 cm compr., estriado, canaliculado, tricomas escamosos; estípulas em forma de esporas (calcaradas), 0,5-0,8 cm compr., tricomas escamosos, limbo elíptico-lanceolado, 7,5$13 \times 2,5-4 \mathrm{~cm}$, discolor, cartáceo a subcoriáceo, ápice curtamente acuminado, base obtusa com um par de glândulas minúsculas, margem inteira, face abaxial pardacenta ou argêntea, com nervura principal proeminente, as secundárias, paralelas entre si, planas e pouco perceptíveis a olho nu, denso indumento de tricomas escamosos; face adaxial com nervura principal impressa, as secundárias planas a levemente impressas, glabras. Inflorescências bissexuadas em racemos,
12-18 cm compr., raque estriada, com tricomas escamosos, flores estaminadas reunidas em glomérulos, as pistiladas isoladas, dispostas na base; flores estaminadas com pedicelo 1,5 mm compr., tricomas escamosos, cálice 4 lobado, lobos sagitados, 2-2,5 mm compr., tricomas escamosos, estames 12 , livres, 2,5-3,0 mm compr., filetes com tricomas vilosos, anteras elípticas, pétalas 5, livres, $2 \mathrm{~mm}$ compr., lanceoladas, com tricomas vilosos especialmente na face externa; flores pistiladas maiores, pedicelo $0,5-0,7 \mathrm{~cm}$ compr., cálice 5-lobado, lobos $4 \mathrm{~mm}$ compr., sagitados, tricomas escamosos na face externa, estrelados pluriramificados na face interna, ovário 3-locular, 5 mm diâm., os lóculos dilatados, denso indumento de tricomas escamosos, estiletes 3, com os ramos bífidos a trífidos, tricomas estrelados pluriramificados na base. Frutos cápsulas, 3 mericarpos, fragmentados, ca. 7-8 mm diâm., indumento de trico-mas escamosos; sementes 3 , rugosas, $5 \mathrm{~mm}$ compr., carunculadas.

Amazonas, Pará (rio Trombetas), Mato Grosso, Rondônia e possivelmente na Bolívia (Pando). 
Nome vulgar: dima (Amazonas)

13.XII.1995 (fl) Brito, J. M. et al. 16 (INPA K MBM MGMO NY RB SP); 5.I.1977 (fl) Nascimento, J. R. 287 (INPA); 8. XII.1994 (fl) Nascimento, J. R. 682 (G IANINPA KMGR SPUUB); 16.I.1964 (fl) Rodrigues, W. \& Monteiro, O. P. 5676 (INPA); 7.III.1968 (fr) Rodrigues, W. et al. 8478(INPA); 9.V.1969 (fl) Souza, J. A. de 286(INPA); 22.III.1994 (fr) Vicentini, A. et al. 430 (IAN INPA K MG NY RB SP).

Croton matourensis é uma grande árvore, com casca bastante estriada e seiva pegajosa vermelha, que se caracteriza facilmente por apresentar as folhas secas com a face abaxial pardacenta, brilhosa, algumas vezes prateada, com denso indumento de tricomas escamosos; as inflorescências em racemos, com as flores pistiladas maiores, dispostas na base, e as flores estaminadas reunidas em densos glomérulos no restante da raque.

Croton lanjouwensis foi um nome novo proposto por Jablonski (1965) para $C$. matourensis var. benthamianus.

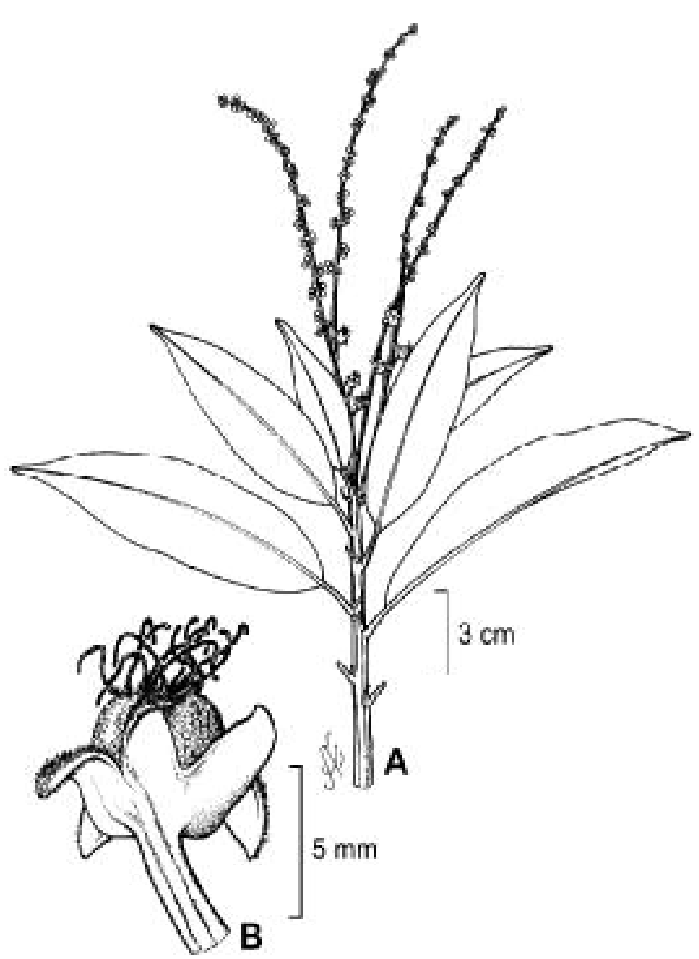

Figura 13 - Croton matourensis. A. Ramo com inflorescências bissexuadas, as flores pistiladas na base. B. Flor pistilada.
12.2 Croton sampatik Müll. Arg., Linnaea 34: 94. 1865. Fig. 14

Árvores 12-20 m de alt., 7-30 cm DAP. Ramos com tricomas escamoso-estrelados. Folhas trinervadas na base, com pecíolo 2,5$5,5 \mathrm{~cm}$ compr., cilíndrico a levemente canaliculado, indumento de tricomas estrelados; limbo oval a oval-lanceolado, 9,5-15×5-9,5 cm, cartáceo a membranáceo, ápice acuminado, base cordada com um par de glândulas salientes, verrucosas, margem inteira a espaçadamente denteada; face abaxial com nervuras proeminentes, indumento de tricomas estrelados; face adaxial com nervuras levemente proeminentes a planas, esparsamente pubescente, os tricomas concentrados nas nervuras. Inflorescências estaminadas em racemos, $20 \mathrm{~cm}$ compr., as flores dispostas em fascículos, raque com denso indumento de tricomas estrelados; flores estaminadas com pedicelo $0,5-0,8 \mathrm{~cm}$ compr., pubescente; cálice 5-lobado, os lobos sagitados, $2 \mathrm{~mm}$ compr., pubescentes, tricomas estrelados; pétalas 5, livres, 2-2,5 mm compr., elípticas, indumento de tricomas simples, vilosos internamente, concentrados nas margens e parte apical, glabras externamente; estames 11-12, livres, $2 \mathrm{~mm}$ compr., assentados em um tufo de tricomas simples, filetes glabros, anteras ovais. Inflorescências bissexuadas (em estágio muito jovem) em racemo espiciformes, as flores pistiladas na base, as estaminadas no restante da raque, raque tomentosa com tricomas estrelados; flores estaminadas em estágio muito jovem; flores pistiladas (ainda jovens) com pedicelo 1 mm compr., tomentoso; cálice 5-lobado, lobos lanceolados, ca. $2 \mathrm{~mm}$ compr., indumento de tricomas estrelados externamente, ovário 3locular, tomentoso, indumento estrelado. Frutos cápsulas, deiscência loculicida, $1 \mathrm{~cm}$ diâm., indumento de tricomas estrelados; sementes 3, com $6 \mathrm{~mm}$ compr., lisas, pintalgadas, ecarunculadas.

Amazonas e Pará (Serra dos Carajás). 12.X.1994 (fl) Vicentini, A. \& Pereira, E. da C. 735 (IANINPA KMGMONYRBSPUB); 12.XII.1995(fr) 


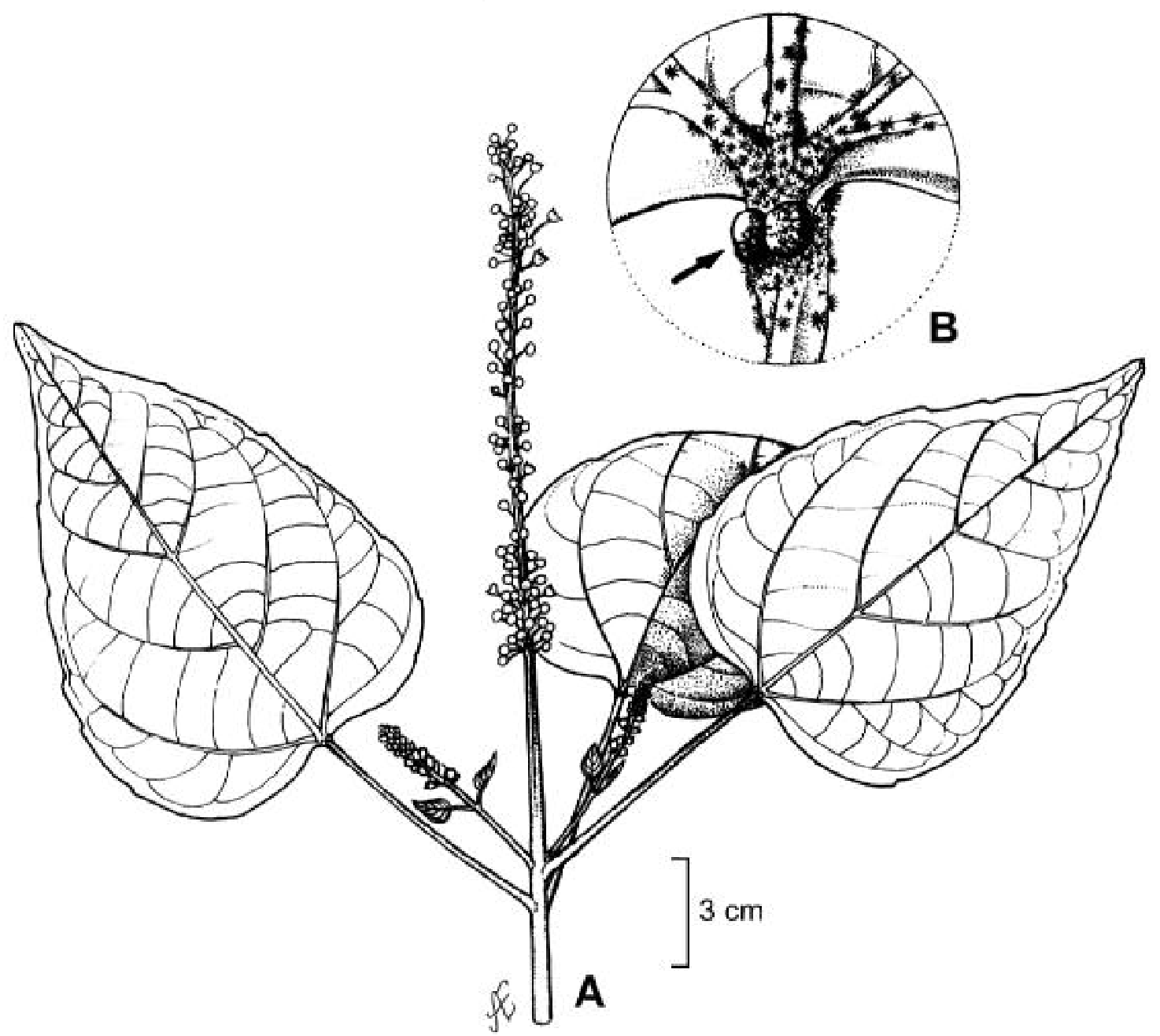

Figura 14 - Croton sampatik. A. Ramo com inflorescência bissexuada. B. Detalhe da base foliar, evidenciando as glândulas (seta).

Vicentini, A. \& Pereira, E. da C. 1164 (INPA K MG MONYRBSP).

Croton sampatik é facilmente identificável pelas folhas ovais, com base trinervada, com indumento de tricomas estrelados; as flores são pediceladas, dispostas em fascículos, com os estames glabros, assentados em um tufo de tricomas; as sementes são lisas, pintalgadas e ecarunculadas.

Esta espécie foi identificada anteriormente como C. matourensis Aublet, com o que discordamos após analisar o tipo daquele táxon, gentilmente cedido pelo herbário de Harvard University $(G)$.

\section{Amanoa}

Amanoa Aubl., Hist. Pl. Guiane 1: 256, pl. 101. 1775.

Árvores ou arbustos monóicos. Ramos glabros. Folhas alternas, inteiras, estípulas intrapeciolares. Inflorescências em racemos, algumas vezes em panículas; flores estaminadas diclamídeas, com sépalas maiores que as pétalas, pétalas diminutas, estames 5, livres, filamentos mais curtos que as anteras, pistilódio conspícuo; flores pistiladas diclamídeas, com sépalas maiores que as pétalas, pétalas diminutas, ovário 3carpelar, óvulos 2 em cada lóculo, estigmas espessos. Fruto cápsula maciça, endocarpo 
geralmente bastante espesso, columela central maciça; sementes geralmente 3 por cápsula, ovais ou elípticas, lisas, ecarunculadas.
Gênero representado por 16 espécies, a maioria neotropical, sendo apenas 3 referidas para a África.

\section{Chave para as espécies de Amanoa na Reserva Ducke}

1. Inflorescências bissexuadas em racemos; ovário com sulcos e lobos; estigmas reflexos, rugosos; fruto com endocarpo espesso 1. A. guianensis

1. Infloescências bissexuadas frequentemente em panículas; ovário sem sulcos e lobos; estigmas não reflexos, formando estrutura estrelada, lisos; fruto com endocarpo fino 2. A. gracillima

13.1 Amanoa guianensis Aubl., Hist. Pl. Guiane 1: 256, pl. 101. 1775. Fig. 15

Árvores $15 \mathrm{~m}$ alt. Ramos lisos, esbranquiçados, glabros. Folhas com pecíolo 1-1,5 cm compr., canaliculado, glabro, enegrecido no material seco, estípulas intrapeciolares (?) discretas; limbo elíptico a elíptico-oblongo, 8,5-12 cm compr., 4-6,5 cm larg., coriáceo, ápice curtamente acuminado, base levemente cuneada, margem inteira; face abaxial com nervuras proeminentes (especialmente a principal), glabra; face adaxial com nervuras planas, a principal podendo ser discretamente proeminente, glabra. Inflorescências bissexuadas em racemos, 5-6 cm compr., axilares ou terminais, as flores dispostas em glomérulos, envolvidas por bractéolas, a raque glabra; flores estaminadas (analisadas em botões) subsésseis a sésseis, cálice 5-lobado, os lobos sagitados, espessos, 4-4,5 mm compr., glabros; estames subsésseis (?), glabros, anteras maiores 3-3,5 mm compr., sagitadas, pistilódio trilobado no ápice, disco pouco conspícuo, ondulado, basal, pétalas unguiculadas 5, diminutas, levemente franjadas, ca. $1 \mathrm{~mm}$ compr., 1,2-1,5 mm larg., glabras; flores pistiladas em geral isoladas entre as estaminadas, pedicelo ca. $1 \mathrm{~cm}$, glabro, sépalas 5, sagitadas, 7-7,5 mm compr., com a margem fimbriada na parte apical, pétalas 5, diminutas, orbiculares, ca. 1,5 $\mathrm{mm}$ compr., $2 \mathrm{~mm}$ larg., as margem fimbriada, glabra, disco basal segmentado, ovário em forma de botija, 3-locular, 5-5,5 mm compr., com sulcos e lobos, glabro, estigmas 3, subsésseis, carnosos, rugosos, reflexos, bífidos, glabros. Fruto cápsula, com endocarpo bastante espesso, ca. 2 cm diâm., glabro; sementes 3, ovais, lisas.
Brasil (Amapá, Roraima, Amazonas, Pará, Maranhão, Rondônia e Bahia), Peru e Guianas.

27.IV.1994 (fl) Ribeiro, J. E. L. S. et al. 1274 (IAN INPA K MG MONYSP);

Material adicional: Amazonas, Itupiranga, rio Uatumã, Cidet al. 612 (INPAMG), 21.VIII.1979 (fr); Amazonas, Cauamé, Ducke 1390 (MG), 7.IX.1943 (fl).

Amanoa guianensis caracteriza-se por apresentar as folhas elípticas a elípticooblongas, com o pecíolo enegrecido no material seco e as inflorescências em racemos, com as flores estaminadas em glomérulos e as pistiladas maiores dispostas entre as estaminadas; os frutos são bem característicos pelo endocarpo espesso e lenhoso (no material seco).

13.2 Amanoa gracillima Hayden, Brittonia 42(4): 262. 1990. Fig. 16

Árvores 10-30 m de alt., 30-40 cm DAP, raízes tabulares, seiva escassa, transparente. Ramos com leves estriações, glabros. Folhas com pecíolo 0,4-1 cm compr., canaliculado, enegrecido no material seco, glabro; limbo elíptico a elíptico-oblongo, raramente elípticolanceolado, 6-13×3-6 cm, coriáceo, ápice acuminado, base levemente cuneada, margem inteira; face abaxial com nervuras proeminentes, especialmente a principal, glabra; face adaxial com nervura principal levemente proeminente a plana, as demais planas a levemente impressas, glabra. Inflorescências bissexuadas em panículas mal definidas, às vezes em racemos, as flores estaminadas em glomérulos envolvidas por bractéolas, as pistiladas isoladas entre as estaminadas; flores estaminadas em estágio 


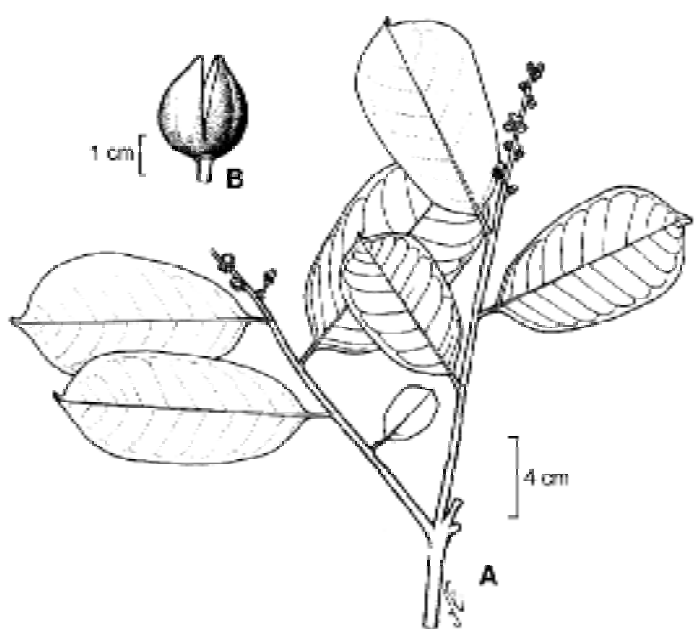

Figura 15 - Amanoa guianensis. A. Ramo com flores estaminadas. B. Fruto.

jovem, subsésseis (?), cálice 5-lobado, lobos imbricados, ca. 3 mm compr., glabros, estames sésseis (?), disco ondulado, pistilódio 3-lobado no ápice, pétalas 5 , diminutas, ca. $1 \mathrm{~mm}$ compr., levemente franjadas; flores pistiladas com pedicelo 3-4 $\mathrm{mm}$ compr., glabro, sépalas 5, livres, sagitadas, 3-3,5 mm compr., 1,5-2 mm larg., glabras, pétalas 6, flabeladas, estreitas na base, largas no ápice, ca. $1 \mathrm{~mm}$ compr., levemente franjadas na região apical, ovário 3-locular, sem sulcos, 2,5$3 \mathrm{~mm}$ compr., $2 \mathrm{~mm}$ larg., subgloboso, glabro, estigmas 3 , bífidos, formando uma estrutura estrelada. Frutos cápsula, endocarpo fino, pouco espessado; sementes 3 , piramidais, marrons, ca. $0,8 \mathrm{~cm}$ compr.

Endêmica do estado do Amazonas. 20.X.1995 (fl) Costa, M. A. S. \& Assunção, P.A. C. L. 404 (BM IAN INPA K MBM MG PUEFR SPVEN); 11.II.1995 (fl) Hopkins, M. J. G. et al. 1538 (COL INPA K MG MO NY RB SPUFMT); 25.X. 1995 (fl) Sothers, C.A. \& Pereira, E. da C. 643 (G IAN INPA KMG SP SPF U UB); 23.II.1996 (fr) Sothers, C. A. \& Pereira, E. da C. 803 (IAN INPA K MG MO NY RB SPUB); 15.XII.1995 (fl) Vicentini, A. \& Silva, C. F. da 1169 (IAN INPA K MG SPUEC US).

Amanoa gracillima é uma árvore grande, com raízes tabulares, apresentando uma seiva escassa, pegajosa e transparente, com as inflorescências em panículas, as vezes
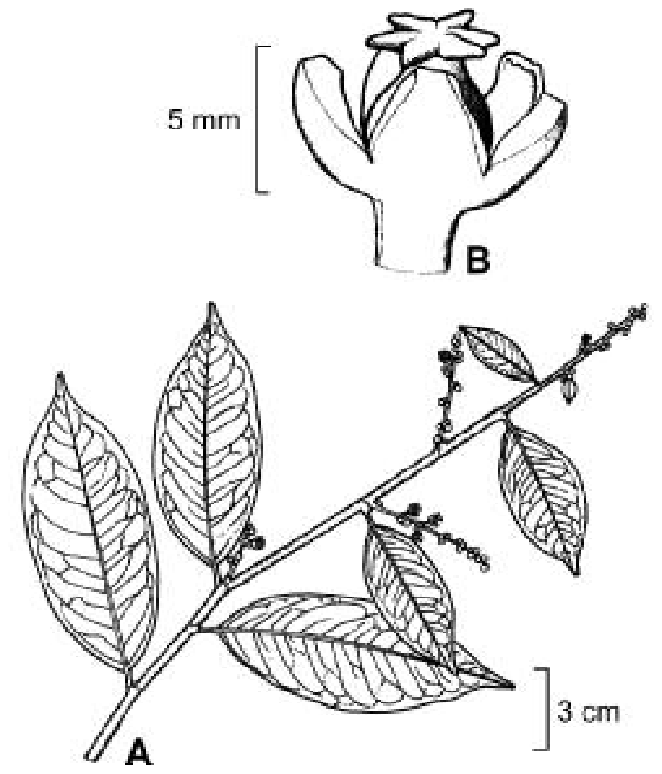

Figura 16 - Amanoa gracillima. A. Ramo com flores pistiladas. B. Flor pistilada.

em racemos; o fruto é diferente daquele de Amanoa guianensis por ser menor e apresentar o endocarpo mais fino; o ovário não apresenta sulcos e os estigmas formam uma estrutura estrelada.

\section{Micrandra}

Micrandra Benth., Hooker's J. Bot. Kew Gard. Misc. 6: 371. 1854. Nom. cons.

Árvores monóicas. Ramos glabros. Folhas alternas, peninérveas, estipuladas, pecíolo com glândulas no ápice ou na base da lâmina. Inflorescências bissexuadas em panículas ou panículas compostas, axilares ou terminais, flores apétalas. Flores estaminadas com cálice 5-lobado, estames 4-10, filetes livres ou levemente concrescidos na base, pistilódio presente; flores pistiladas com sépalas 5, livres, disco presente ou não, ovário 3-carpelar, óvulo 1 por lóculo, estiletes curtos. Fruto cápsula, globoso a trilobado; sementes 3 , carunculadas ou ecarunculadas.

Gênero com ca. 7 espécies, distribuídas na Amazônia. Ainda está mal coletado na região, sendo representado nos herbários por coleções pouco satisfatórias. 


\section{Chave para as espécies de Micrandra na Reserva Ducke}

1. Folhas glabras na face abaxial; inflorescências bissexuadas em panículas compostas, densas; estames 8; ovário glabro 1. M. spruceana

1. Folhas com domácias de tricomas na fase abaxial; inflorescências bissexuadas em panículas laxas; estames 5; ovário tomentoso

2. M. siphonoides

14.1 Micrandra spruceana (Baill.) R. E. Schultes, Bot. Mus. Leafl. 15: 217. 1952. Fig. 17

Cunuria spruceana Baill., Adansonia 4: 288.1864

Árvores 20-30 m alt., 45 cm DAP, com látex branco. Ramos levemente estriados, glabros, com muitos líquens. Folhas com pecíolo 3-4 cm compr., canaliculado, glabro; limbo elíptico, 10-13×4-5 cm, coriáceo, ápice agudo, base levemente cuneada, com um par de glândulas, margem inteira, levemente ondulada; face abaxial com nervuras proeminentes, especialmente a principal, glabra; face adaxial com nervuras levemente proeminentes a planas, glabra. Inflorescências bissexuada em panícula composta, densa, 4-8 cm compr., as flores estaminadas agrupadas, as pistiladas geralmente nas terminações da raque, raque glabra; flores estaminadas (vistas em botões), subsésseis (?), cálice 5-lobado, ca. $4 \mathrm{~mm}$ compr., os lobos ovais a sagitados, imbricados, pubescentes, tricomas simples, estames 8 , ca. $2 \mathrm{~mm}$ compr., concrescidos na base, assentados em um disco pentalobado, com tricomas vilosos no ápice, pistilódio central; flores pistiladas com pedicelo 2,5$3 \mathrm{~mm}$ compr., grosso, glabro, sépalas 5, com 5-6 mm compr., livres, elípticas, pubescentes externa e internamente, ovário piriforme, 3locular, $3 \mathrm{~mm}$ compr., $2 \mathrm{~mm}$ larg., glabro, assentado em disco lobado, com prolongamentos espiculados apicais, estigmas 3, sésseis, bífidos. Frutos não vistos.

Colômbia, Peru e Brasil (Roraima, Amazonas e Pará).

30.IV.1995 (fl) Ribeiro, J. E. L. S. et al. 1625 (IAN INPA K MBM MG MO NY RB SP); 29.VIII.1957 (st) Rodrigues, W. 580 (INPA).
Micrandra spruceana caracteriza-se por apresentar as inflorescências em panículas compostas densas, as flores estaminadas sésseis a subsésseis e o ovário glabro.

14.2 Micrandra siphonioides Benth., Hooker's J. Bot. Kew Gard. Misc.6: 371. 1854. Fig. 18 Árvores $15-25 \mathrm{~m}$ alt., $15-45 \mathrm{~cm}$ DAP, com o fuste tortuoso, tronco rugoso, soltando lascas, madeira avermelhada, látex branco. Ramos rugosos, glabros. Folhas com pecíolo 2-5 cm compr., levemente canaliculados, glabros. Limbo oboval a oblongo-elíptico, pubescente nos ramos jovens, coriáceo, ápice agudo a levemente acuminado, base obtusa a levemente cuneada, margem inteira; face abaxial com nervuras proeminentes, domácias de tricomas simples na junção da nervura principal com as secundárias; face adaxial com nervuras planas a levemente proeminentes, glabra. Inflorescências bissexuadas em panículas laxas, 3,5-10 cm compr., a raques pubescente, as flores estaminadas isoladas, aos pares ou em tríades, as pistiladas mais raras, isoladas nas terminações; inflorescências pistiladas (?) em panículas, 4-6,5 mm compr., raques estriadas, pubescentes; flores estaminadas com pedícelo 2-3 $\mathrm{mm}$ compr., pubescentes; cálice 5-lobado, lobos 3-5 cm compr., ovais, pubescentes externamente, rugosos e glabros internamente; estames 5 , livres, 4-4,5 cm compr., glabros, anteras elípticas, disco segmentado, com tricomas simples, pistilódio (?) central, mais ou menos achatado, pubescentes; flores pistiladas com pedicelo $3-5 \mathrm{~cm}$ compr., pubescente, sépalas 5, elíptico-lanceoladas, 4-5 mm compr., pubescentes externamente, rugosas e glabras internamente, ovário 3-locular, piriforme, com 


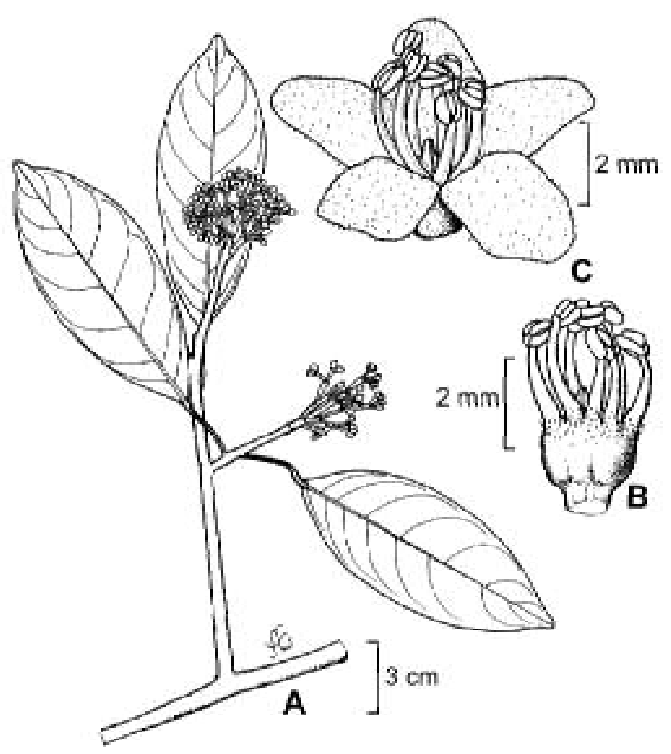

Figura 17 - Micrandra spruceana. A. Ramo com inflorescências estaminadas. B. Detalhe do androceu. C. Flor estaminada.

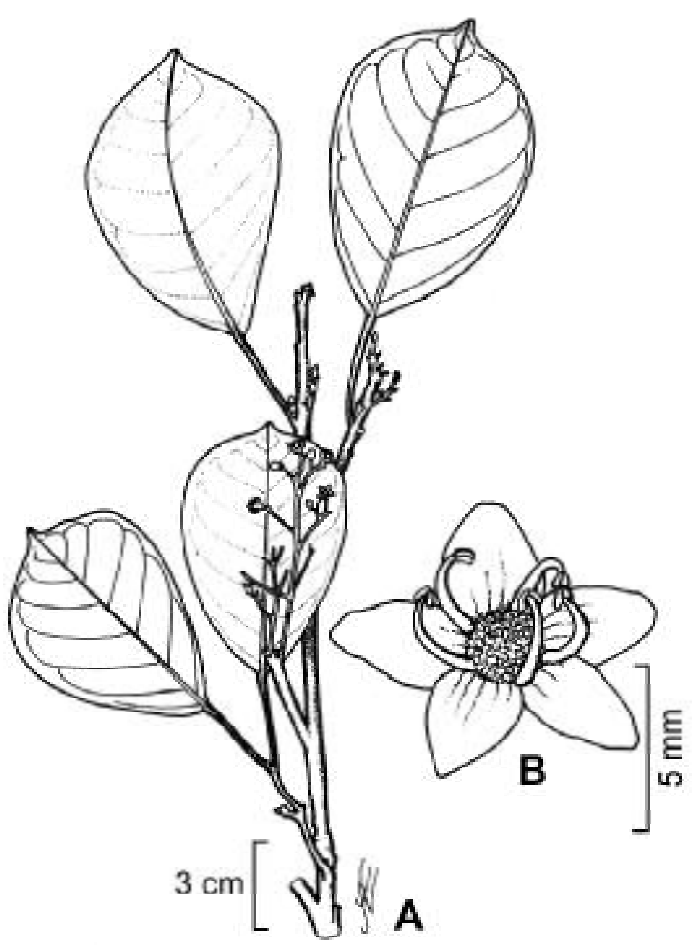

Figura 18 - Micrandra siphonioides. A. Ramo com inflorescências estaminadas. B. Flor estaminada. lobulações, tomentoso, tricomas simples, $3 \mathrm{~mm}$ compr., 2 mm diâm., estiletes 3, bífidos. Frutos não vistos.

Colômbia, Brasil (Amapá e Amazonas) Nome vulgar: seringarana.

9.VII.1995 (fl) Lohmann, L. G et al. 6 (GIAN INPA K MG SP U UB US); 28.VII.1994 (fl) Nascimento, J.R. \& Pereira, E. da C. 554 (IANINPA K MG MONYR RB SP); 6.VI.1993 (fr) Ribeiro, J. E. L. S. et al. 893 (INPA K MGNY SP); 2.VIII.1994 (fl) Ribeiro, J. E. L. S. \& Silva, C. F. da 1356 (INPA K MG SP); 14.VIII.1957(fl) Rodrigues, W. 532 (INPA); 25.VIII.1994 (bt) Sothers, C. A. et al. 139 (BM IAN INPA K MBM MGSPVEN).

Micrandra siphonoides se caracteriza por apresentar as folhas com domácias de tricomas na face abaxial, as inflorescências bissexuadas em panículas laxas, com as flores estaminadas pediceladas e o ovário tomentoso.

\section{Glycydendron}

Glycydendron Ducke, Arch. Jard. Bot. Rio de Janeiro 3: 199. 1922.

Gênero monotípico distribuído na Amazônia brasileira.

15.1 Glycydendron amazonicum Ducke, Arch. Jard. Bot. Rio de Janeiro 3: 199. 1922. Fig. 19

Árvores dióicas, $15-30 \mathrm{~m}$ alt., $35-40 \mathrm{~cm}$ DAP, com látex branco escasso. Ramos estriado-rugosos, pubescentes a glabros. Folhas palmatinérveas, base trinervada, com pecíolo 3-5 cm compr., levemente canaliculado, glabro; limbo elíptico, 10-20×6-9 cm, coriáceo, ápice curtamente acuminado, base cuneada, margem inteira; face abaxial com nervuras proeminentes, glabra; face adaxial com nervuras planas a levemente proeminentes, glabra. Inflorescências estaminadas em panículas, $2-5 \mathrm{~cm}$ compr.; flores estaminadas pediceladas, com sépalas 4, imbricadas, estames 25-30, livres, disco interestaminal com tricomas (Ducke 1922); inflorescências pistiladas em racemos, 2,5$4,5 \mathrm{~cm}$ compr., flores pistiladas monoclamídeas, sépalas 4, ovário oval, tomentoso (?), 2-locular, estames 2, sésseis, profundamente 


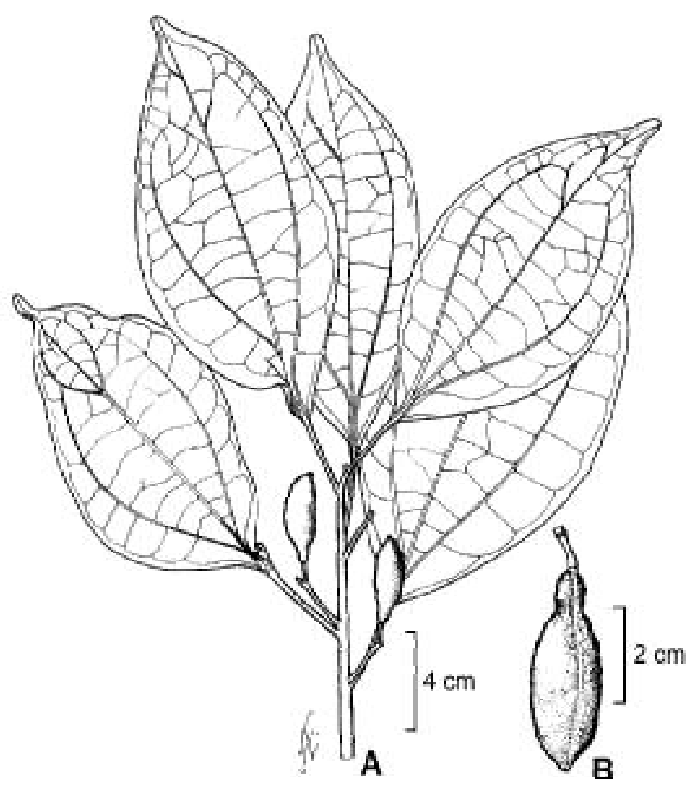

Figura 19 - Glycydendron amazonicum. A. Ramo com frutos. Fruto em detalhe. bífidos. Frutos drupas, ovóides a elípticos, 4$4,5 \mathrm{~cm}$ compr., amarelos, rugosos no material seco; sementes não analisadas.

Guiana e Brasil (Amapá, Amazonas, Pará, Rondônia e possivelmente no Maranhão-São Luís).

Nome vulgar: pau doce.

21.I.1997 (fr) Assunção, P.A. C. L et al. 461 (BM INPA KMBMMG MO NY RB SP); 6.XI.1995 (fl) Costa, M. A. S. \& Silva, C. F. da 419 (IAN INPA K MBM MG MONY RB SP); 19.VI.1958 (fl) Coêlho, L. 19(INPA); 31.VIII.1966 (fr) Prance, G. T. et al. 2116 (INPA); 25.VIII.1964 (fr) Rodrigues, W. \& Monteiro, O. P. 6013 (INPA); 28.IV.1966 (fl) Rodrigues, W. \& Coêlho, D. 7731 (INPA); 18.VIII.1966(fr) Rodrigues, W.\& Monteiro, O.P. 8229 (INPA); 24.IV.1995 (fl) Sothers, C. A. \& Silva, C. F. da 407 (G IAN INPA K MG SP U UB UEC); 24.IV.1995 (fl) Vicentini, A. et al. 944 (INPA SP); 6.IX.1995 (fr) Vicentini, A. et al. 1015 (G IAN INPA K MG SPU UB UEC); 18.IX.1995 (fr) Vicentini, A. \& Silva, C. F. da 1026 (IAN INPA K MG SP SPF US).

Glycydendron amazonicum é uma espécie inconfundível por apresentar as folhas palmatinérveas, trinervadas na base, elípticas, com a base cuneada e os frutos do tipo drupa, ovóides a elípticos. 
